\title{
Terry in the Age of Automated Police Officers
}

\author{
Ric Simmons*
}

Robots are now commonplace tools for law enforcement. The current generation of police robots is largely limited to remote-controlled robots that are designed to perform specific tasks, such as search-and-rescue drones and bomb-disposal robots. But the use of robots in law enforcement is likely to increase dramatically in the near future, since robots provide numerous benefits to police departments, including greater efficiency, increased capability, and enhanced safety for human officers. Therefore, in the near future, law enforcement agencies will begin to deploy semi-autonomous robots for two primary and interrelated functions: surveillance and patrol.

These new machines will dramatically increase the number of interactions between civilians and police robots, which will force courts to reconsider the rules of engagement for when police confront suspects. Many of the existing rules give the police broad powers to search or use force in order to protect officer safety; however, if no human police officer is on the scene, there is no justification for these broad powers.

Specifically, although semi-autonomous police robots will be permitted to conduct Terry stops (and will likely be more accurate in determining reasonable suspicion), they will not be permitted to conduct a frisk. These robots will also not be permitted to conduct protective sweeps of homes when making an arrest, nor engage in a protective search of a car during a traffic stop, and their power to conduct a search incident to an arrest will be limited. Courts will also need to revisit the use-of-force rules when applying them to robot police officers; these machines will almost never be permitted to use deadly force, and their use of non-deadly force will be strictly curtailed. The result will be an increase in visual surveillance - as more robot police with enhanced sensory capabilities are deployed - but a decrease in physical surveillance and physical altercations between police and civilians.

*Chief Justice Thomas J. Moyer Professor for the Administration of Justice and Rule of Law, Michael E. Moritz College of Law, The Ohio State University. Thanks to Angela Lloyd, Bennett Capers, Jonathon Witmer-Rich, Paul Belonick, Andrew Crespo, and the participants of the 2019 CrimFest conference for invaluable suggestions and feedback. Thanks also to Shahrzad Shams and Jack Rozema for their research assistance. A special thanks to Hayden Capace for the original idea that led to this article. 
I. INTRODUCTION 910

II. A BRIEF PRIMER ON POLICE ROBOTS.................................. 912

A. A Taxonomy of Robots ....................................... 912

B. The Present and Near Future of Police Robots .............. 913

C. Benefits and Costs of Police Robots .......................... 916

D. The Capabilities of Robot Police to Search, Seize, and Arrest Suspects.

III. How Robot Police OFFICERS Will Change Fourth AMENDMENT DOCTRINE 923

A. The Expansive Powers Granted by the "Officer Safety" Rationale 925

1. Terry v. Ohio 925

2. Search Incident to Lawful Arrest ......................... 936

B. Use-of-Force Situations ...................................... 941

IV. HYDRAULIC PRESSURES AND EQUILIBRIUM ADJUSTERS ......... 944

V. CONCLUSION 952

\section{INTRODUCTION}

For decades, police robots have been a staple of science fiction. ${ }^{1}$ These fictional machines are usually fully autonomous, independently making

1 The most famous portrayal of a police robot is Robocop, who stars in a trilogy of eponymous movies from the late 1980s and early 1990s and is also the subject of a reboot in 2014. Robocop is technically a cyborg (part human and part machine), and he is portrayed as a moral hero and also as an incredibly effective, nearly unstoppable, crime-fighting tool. Robocop's programming forbids him from harming innocent people or breaking the law. The Robocop movies also feature an all-machine robot, known as the ED-209, which carries absurdly heavy firepower for domestic law enforcement and whose programming apparently allows it to fatally shoot civilians within seconds if the civilian does not obey its commands. See Rовосор (Orion Pictures 1987). Another, less famous robot police officer is R Daneel Olivaw, who originally appeared in Isaac Asimov's Caves of Steel and made numerous appearances in other books. Daneel is also portrayed as a hero, and since he is bound by the Laws of Robotics, he cannot harm any people, guilty or innocent. See IsAac Asimov, The CAVES OF STEEL (Doubleday 1954). More commonly, robot police officers appear as plot devices or background characters in science fiction, serving to make the setting more "futuristic." See e.g., STAR TREK (Paramount Pictures 2009) (a robot police officer on a hoverbike attempts to pull over a pre-teenage James Kirk who is joyriding in his stepfather's car). In these examples too, though, robot police officers are usually portrayed as law-abiding, helpful, protective of humans, respectful, and efficient.

These portrayals of robot police officers contrast with robots' general portrayal in science fiction, which is usually violent and/or destructive to society, usually because of their programming or their reaction to being treated poorly by humans. See, e.g., 2001: A SPACE ODYSSEY (Metro-Goldwyn-Mayer 1968) (HAL 9000 kills the crew of a spaceship); THE TERMINATOR (Cinema ' 84 1984) (T-800 sent back in time to kill the mother of the future leader of the human resistance; in later sequels, the T-800s were programmed to protect humans, but inevitably other robots are sent back to kill those humans); BLADE RUNNER 
critical decisions about when to arrest a suspect and whether to use deadly force. Thus, their programmers must give these robots specific directives that guide their interactions with civilians. Almost uniformly, these directives result in robot officers that are more law-abiding and respectful to civilians than the average human police officer. ${ }^{2}$

Police robots have now moved out of the realm of science fiction, onto our streets, and into the skies above us. Hundreds of police departments across the country use robots for specific tasks, such as aerial search-andrescue and bomb disposal. ${ }^{3}$ In 2016, a Dallas police department ended a standoff with an active shooter by using a remote-controlled robot to kill the suspect with explosives. ${ }^{4}$ This incident set off a flurry of attention on the use of police robots, both in the national news ${ }^{5}$ and in legal academia. ${ }^{6}$ These news stories and articles focused on the legal challenges posed by arming police robots. Many discussed how to program robots to ensure that theylike the police robots of science fiction-always obey the law when

(Warner Bros. 1982) (Replicants escape from space mining camps and come to Earth to find their creator, killing numerous humans along the way).

2 The original Robocop famously has four directives: (1) Serve the public trust; (2) Protect the innocent; (3) Uphold the law; and (4) Any attempt to arrest a senior officer of the corporation that created him results in shutdown. The first three make him a perfect, hyperethical police officer; the fourth is an Easter Egg inserted by a high-level corrupt corporate officer so that Robocop cannot arrest him for their own malfeasance. See RoBOcop, supra note 1. Daneel Olivaw follows the Laws of Robotics: (1) A robot may not injure a human being or, through inaction, allow a human being to come to harm; (2) A robot must obey the orders given to it by human beings, except where such orders would conflict with the First Law; and (3) A robot must protect its own existence as long as such protection does not conflict with the First or Second Laws. These force him to be protective of humans but also mean that he has to rely upon human police partners to conduct some parts of a police officer's job. See CAVES OF STEEL, supra note 1.

3 See infra notes 12-13 and accompanying text.

4 See Henry Fountain \& Michael S. Schmidt, "Bomb Robot” Takes down Dallas Gunman, but Raises Enforcement Questions, N.Y. TIMES (July 8, 2016), https://www.nytime s.com/2016/07/09/science/dallas-bomb-robot.html.

5 See, e.g., E.B. Boyd, Is Police Use of Force About to Get Worse-With Robots?, Politico (Sept. 22, 2016), https://www.politico.com/magazine/story/2016/09/police-robotsethics-debate-214273.

6 See, e.g., Elizabeth E. Joh, Policing Police Robots, 64 UCLA L. REV. DisCOURSE 516 (2016); Zachary A. Kaplan, Note, R2D2 or iRobot: Can Armed Robots Be a Friend to Police Without Being a Foe to the Public?, 32 Notre Dame J. L., Ethics \& Pub. PoL'y 603 (2018); Michael Sinclair, Proposed Rules to Determine the Legal Use of Autonomous and SemiAutonomous Platforms in Domestic U.S. Law Enforcement, 20 N.C. J.L. \& TECH. 1, 12 (2018); Thomas Wanebo, Comment, Remote Killing and the Fourth Amendment: Updating Constitutional Law to Address Expanded Police Lethality in the Robotic Age, 65 UCLA L. REV. 976 (2018). Even before the 2016 incident in Dallas, regulating deadly use of force was the primary focus of most scholarship on police robots. See also Alexandra A. Breshears, Comment, Use of Armed Drones by Domestic Law Enforcement: Presence and the Fourth Reasonableness Factor, 33 W. Mich. U. CoOLEy L. REV. 183 (2016). 
detaining suspects or using force against civilians. These questions are somewhat premature, since modern-day police robots never act autonomously when they interact with civilians. But even the remotecontrolled and semi-autonomous robots of today present challenges to some of the fundamental doctrines governing police power and privacy rights.

Over the next decade, police will be using robots for routine tasks such as surveillance and patrol, which will dramatically increase the number of interactions between civilians and police robots. ${ }^{7}$ This development will force courts to reconsider the rules of engagement that they have set down for when police confront suspects. Many of the existing rules give the police broad powers to search or use force in order to protect officer safety, and if a human police officer is no longer on the scene, there is no justification for these broad powers. This article argues that robot police officers will represent a trade-off for police departments: policing will be safer and more efficient, but the legal authority of robot police officers will be curtailed.

Part I of this article will provide an overview of how the public and private police currently use robots and look ahead to how robots will be used in the future. Part II examines how the use of these robots will undermine the current legal regime governing police/civilian interaction, including Terry stops, searches incident to a lawful arrest, and regulations on use of force. Part III reflects on how the equilibrium adjustment theory will apply to this new development, and discusses how police will adjust their behavior to conform to the new rules. It is possible that Terry frisks have become such a foundational tactic of law enforcement that courts will change the justification for the frisks to allow them to continue even when officer safety is not threatened. ${ }^{8}$

\section{A BRIEF PRIMER ON POLICE ROBOTS}

\section{A. A Taxonomy of Robots}

The most common definition of a robot is "any machine that can collect information, process it, and use it to act upon the world." For the purposes of this article, our definition will be a bit different. It will be narrower in the sense that we are only going to include machines that are mobile and can act in a physical, rather than merely virtual, sense. Thus, a "bot" that exists only on a computer or on the internet will not qualify. It will be broader because it will include any mobile machine that can sense and act, even if it cannot do much in the way of thinking. Using this revised definition, police robots

7 See infra notes 23-34 and accompanying text.

8 See Terry v. Ohio, 392 U.S. 1 (1968). 
can be divided into three categories: remote-controlled, semi-autonomous, and fully autonomous. ${ }^{9}$

"Remote-controlled" robots are mobile machines that do no more than respond to commands from a human operator. These devices have no decision-making ability of their own. Examples of these devices that are currently being used by law enforcement include surveillance drones flown by remote control or bomb-disposal robots controlled by bomb squad technicians. "Semi-autonomous" robots are able to operate without any human input and do so for the majority of the time; however, they are designed for humans to take control during critical moments. These robots are able to navigate on their own and handle simple interactions with civilians, and some of them also have an algorithm built into their programming that evaluates their inputs and determines whether a situation seems suspicious enough to alert their human monitor. Although public police are only just starting to adopt semi-autonomous robots in this country, these devices are becoming more common among private security companies and foreign police forces. Finally, "fully autonomous" robots can conduct all of their operations without any human input. These machines can be designed to complete a set of basic functions, such as patrol an area and interact with the environment or with civilians in pre-programmed ways in response to certain circumstances. ${ }^{10}$ Given the many complex decisions required for policing, fully autonomous police robots do not yet exist outside the realm of science fiction.

\section{B. The Present and Near Future of Police Robots}

The current generation of police robots consists of remote-controlled robots that are designed to perform specific tasks. ${ }^{11}$ These robots are

9 These categories are set out in Sinclair, supra note 6, at 14-15. Like most commentators in this area, Judge Sinclair focuses on the use of force by robots, and notes that for semi-autonomous robots, the critical "decision point" about who should act between the robot and the human occurs at the point where armed force is necessary. Sinclair, supra note 6 , at 14 .

10 In reality, there are no bright lines that separate these three categories. Most remotecontrolled robots have some amount of autonomous programming, such as the ability to perform multi-stepped tasks based on a single command or fly on autopilot if they temporarily lose their connection with their human pilot. And as semi-autonomous robots become more sophisticated, they will be programmed to automatically respond in more complicated ways to a wider range of inputs, until they will rarely need human intervention. Finally, even the fully autonomous robots will likely contain an override so that human beings can take control of the machine in extraordinary circumstances.

11 Even putting aside actual robots, police officers regularly integrate technology into their jobs, by using onboard computers in their cars, big data analysis in their investigations, and smart phone apps, including apps that provide the Miranda warnings and DUI test instructions, apps that search the penal codes and apps that help witnesses identify vehicles 
primarily of two different types: search-and-rescue drones ${ }^{12}$ and bombdisposal robots. ${ }^{13}$ But recently police officers have been using these robots in innovative ways: to conduct basic surveillance, ${ }^{14}$ monitor traffic, ${ }^{15}$ investigate active shooters, ${ }^{16}$ analyze crime scenes, ${ }^{17}$ sweep locations for booby traps before officers enter, ${ }^{18}$ investigate locations that are inaccessible or too dangerous for human police officers, ${ }^{19}$ or even to disable ${ }^{20}$ or disarm suspects. ${ }^{21}$

Recently, law enforcement agencies have begun to adopt semiautonomous robots for two primary and interrelated functions: surveillance and patrol. ${ }^{22}$ Many private security companies already use such devices.

that they saw. This reliance on technology for everyday work tasks in not unique to police officers. Some anthropologists have provocatively declared that modern humans have in many ways already become cyborgs because of our frequent use and dependence on machines to communicate, store and retrieve data, and interact with the outside world. See, e.g., Are Our Devices Turning Us into a New Kind of Human?, NPR TED RADIO Hour (Sept. 11, 2015) (downloaded at https://www.npr.org/2015/09/11/438944317/are-our-devices-turning-usinto-a-new-kind-of-human) (anthropologist Amber Case presents her TED talk "We Are All Cyborgs Now").

12 As of 2018, over 900 police departments were using surveillance drones. See Ashley Southall \& Ali Winston, New York Police Say They Will Deploy 14 Drones, N.Y. TimES (Dec. 4, 2018), https://www.nytimes.com/2018/12/04/nyregion/nypd-drones.html.

13 As of 2016 , there were over 987 bomb detection robots being used by 280 police departments around the country. Dan Gettinger \& Arthur Holland Michel, Law Enforcement Robots Datasheet, CTR. FOR STUDY DRONE BARD C. (July 11, 2016), https://dronecenter.bard.edu/law-enforcement-robots-datasheet/.

14 Marco Margaritoff, Drones in Law Enforcement: How, Where and When They're Used, DRIVE (Oct. 13, 2017), http://www.thedrive.com/aerial/15092/drones-in-lawenforcement-how-where-and-when-theyre-used.

15 Id.

$16 I d$.

$17 \quad I d$

18 Boyd, supra note 5.

19 See Gettinger \& Michel, supra note 13. Some police SWAT teams employ a device called a "throwbot" - a small robot they can throw into a barricaded room or building during a standoff to assess the situation. Id. See also Boyd, supra note 18; Sinclair, supra note 6, at 12 (police departments using robots for bomb disposal and to assist in high-risk entry situations).

20 See Gettinger \& Michel, supra note 13.

21 Richard Winton \& Matt Hamilton, Man vs. Machine: L.A. Sheriff's Deputies Use Robot to Snatch Rifle from Barricaded Suspect, End Standoff, L.A. TimES (Sept. 15, 2016), https://www.latimes.com/local/lanow/la-me-ln-robot-barricaded-suspect-lancaster20160915-snap-story.html.

22 Surveillance involves monitoring certain locations to detect criminal activity; this could involve widespread, continuous monitoring of large areas, or targeted monitoring of a specific person or location upon individualized suspicion. Patrol involves establishing a mobile, physical presence in an area to deter criminal activity and to decrease response time once criminal activity has been detected. See Sinclair, supra note 6, at 12-13.

As of October 2019, the private company Knightscope had leased seventy of their 
One example is the Cobalt robot that patrols the Yelp headquarters in San Francisco. Cobalt robots are approximately five feet tall, shaped like large, blue traffic cones, and equipped with a high-definition camera, a directional microphone, and an infrared sensor. ${ }^{23}$ The Cobalt robot navigates through office buildings autonomously, patrolling for any sign of trouble. ${ }^{24}$ A human monitor watches the video feeds of a number of roaming Cobalts from a remote location. ${ }^{25}$ The robot's programming is able to identify potentially suspicious situations, such as a window that has been left open or the presence of a person in a restricted area, which will trigger an alert to the human monitor. ${ }^{26}$ If the monitor receives an alert, or if she herself sees something on the video feeds that seems suspicious, she takes control of the robot and directs its movements. ${ }^{27}$ The human monitor can also speak through the robot, giving commands to individuals who the robot might encounter, such as an order to scan a security badge into the robot's sensor or a demand to leave the area. ${ }^{28}$ Other fully autonomous robots owned by private security firms patrol shopping malls and parking lots, equipped with thermal imagers that can detect intruders at night and cameras that can read license plates to report speeders or stolen cars. ${ }^{29}$

Public police robots will have a similar job, but on a much larger scale: hundreds of such robots can wheel along city sidewalks, acting as mobile, interactive surveillance cameras, with one police officer supervising ten or twenty devices at a time. If the robot's programming identifies anything unusual, ${ }^{30}$ or the human monitor observes suspicious activity, the monitor can take control of the robot and investigate further by asking questions of

RoboCop models to public police forces around the country. Although they are not yet directly connected to the police departments, they are able to record what is going on around them and deliver that information to the police. The most recent models have a 360-degree high-definition live video stream, the ability to read 1,200 license plates per minute, and the ability to track mobile phone use. See Fabienne Lang, Police Robot Ignores Woman's Call for Help in an American Park, InTERESTING ENG'G (Oct. 10, 2019), https://interestingengineering.com/

police-robot-ignores-womans-call-for-help-in-an-american-park.

23 Robbie Gonzalez, I Spent the Night with Yelp's Robot Security Guard, Cobalt, WIRED (Aug. 4, 2017), https://www.wired.com/story/i-spent-the-night-with-yelps-robot-securityguard-cobalt/.

24 Id.

$25 I d$.

26 Id.

27 Id.

28 Id.

29 Shan Li, Robots Are Becoming Security Guards. "Once It Gets Arms . . It'll Replace All of Us, " L.A. TIMES (Sept. 2, 2016), http://www.latimes.com/business/la-fi-robots-retail20160823-snap-story.html.

30 See infra notes 31-33 and accompanying text for examples of how security robots in other countries identify suspicious behavior. 
the individuals who are present or directing the robot's camera or other sensors to look at specific locations or objects.

Other countries have already begun using semi-autonomous robots for public policing. The "E-Patrol Robot Sherriff" in China patrols public places and uses facial recognition technology to scan for suspects in its database. When it detects a person who is wanted by law enforcement, it alerts the human police and begins following the suspect until the police arrive. ${ }^{31}$ South Korea began testing a five-foot-tall dog-shaped robot named "RoboGuard," which autonomously patrols the corridors of prisons. ${ }^{32}$ Robo-Guard has artificial intelligence that can detect abnormal prisoner activity such as aggressive behavior towards other inmates or suicidal tendencies, and then alert the humans in the control room. ${ }^{33}$ Other countries have police robots that perform more benign law enforcement functions. For example, the police robot in Dubai patrols tourist attractions and shopping malls, and can detect known fugitives using its surveillance camera and facial recognition capabilities, but people can also ask it for directions, pay fines, access police information, and report crimes. ${ }^{34}$

\section{Benefits and Costs of Police Robots}

Many of the benefits of using police robots are obvious. First and foremost, semi-autonomous and fully autonomous robots used for surveillance and crowd control act as a force multiplier. Like many other types of new technology, robots allow police to leverage resources; one police chief said that a drone is "like having twenty police officers on patrol or more." 35 As noted in the previous section, private security agencies save significant resources by using one human to monitor multiple semiautonomous robots on patrol; the robots and the individual officer cost only a fraction of the cost of a human security team. ${ }^{36}$ The ratio of robots to

31 Thomas Page, The Inevitable Rise of the Robocops, CNN (May 22, 2017), https://www.cnn.com/2017/05/22/tech/robot-police-officer-future-dubai/index.html.

32 Elizabeth Fish, Forget RoboCop: Robo-Guard Patrols Korean Prisons, Foresees Trouble, PCWORLD (Apr. 13, 2012), https://www.pcworld.com/article/253713/forget_roboco p_robo_guard_patrols_korean_prisons_forsees_trouble.html.

33 Id.

34 Page, supra note 31.

35 Matt Alderton, To the Rescue! Why Drones in Police Work Are the Future of Crime Fighting, REDSHIFT (Apr. 13, 2018), https://www.autodesk.com/redshift/drones-in-policework-future-crime-fighting/. A CEO of a company that provides drones to police describes his product as "a live version of Google Earth, only with a full TiVo capability ... . It allows us to rewind time and go back and see events that we didn't know occurred at the time they occurred." Id.

36 See Gonzalez, supra note 23. The tech company Yelp hired Cobalt robotics to provide security for their officer park and reported that the cost was "between $\$ 30,000$ (the annual 
human pilots will also increase as the semi-autonomous robots are programmed to deal with more and more situations on their own. ${ }^{37}$ And although robots need maintenance and upkeep, they can work nearly around the clock, and they never call in sick or underperform out of laziness or boredom. ${ }^{38}$ Given the fact that patrol officers typically make up a majority of a police department's budget, ${ }^{39}$ this increased efficiency will allow police to either increase the amount of surveillance and investigation that they perform, or allow them to do the same amount of surveillance and investigation for less money. This would free up resources for more humanbased tasks, such as interviewing witnesses or conducting long-term investigations. ${ }^{40}$

A second benefit of robot police officers is their increased capability. Like many other machines used by police, including Breathalyzers, surveillance cameras, and radar guns, most robots can do things that human beings cannot do. We have already seen that search-and-rescue drones can cover more territory than a human police officer, while bomb-disposal robots can access areas inaccessible to human police officers. ${ }^{41}$ And almost all robots, whether used for patrol or surveillance, have sensors that are more sophisticated than human senses. Aerial drones equipped with thermal imaging have found the bodies of missing persons ${ }^{42}$ and runaway children

cost of monitoring an office full of security cameras) and $\$ 300,000$ (the annual cost of a fleshand-blood security detail)." Id.

37 Id.

38 See Sinclair, supra note 6, at 30-31.

39 See e.g., About NYPD, N.Y.C. POLICE DEP'T, https://www1.nyc.gov/site/nypd/about/a bout-nypd/about-nypd-landing.page (last visited Feb. 25, 2020) (60\% of New York City's uniformed officers, approximately 21,600 officers, are assigned to patrol); City of Chicago Active Employees Overview, OFF. INSPECTOR GEN.,https://informationportal.igchicago.org/ci ty-of-chicago-active-employees/ (last visited Feb. 25, 2020) (60\% of Chicago's uniformed officers, approximately 7,166 officers, are assigned to patrol); Fort Wayne Police Department Annual Report: 2018 A Year in Review, ForT WAYNE POLICE DeP'T, http://www.fwpd.org/w p-content/uploads/2019/03/2018-FWPD-Annual-Report.pdf (last visited Feb. 25, 2020) (60\% of officers of Fort Wayne, Indiana police force, approximately 286 offices, are assigned to patrol); Timothy Gauerke et al., Milwaukee Police Department 2016 Annual Report, MilwaUKEE POLICE DEP'T, https://city.milwaukee.gov/ImageLibrary/Groups/mpdAuthors/A rchive-Annual-Reports/2016SinglePageAnnualFinal.pdf (last visited Feb. 25, 2020) (60\% of Milwaukee's police force, approximately 720 officers, are assigned to patrol duties); FORT Wayne Police DePartment, http://www.fwpd.org/inside-the-fwpd/divisions/ (last visited Feb. 25, 2020); Milwaukee Police Department: Police Districts, https://city.milwaukee. gov/Directory/police/Police-Districts.htm\#.XTnL6HdFxPY (last visited Feb. 25, 2020).

40 Robots are also replacing human officers in other routine tasks, such as traffic management or crowd control, which free up law enforcement resources for more sophisticated work.

41 See Gettinger \& Michel, supra note 13.

42 A police aerial drone in Wisconsin as able to find the body of a man who went missing while ice fishing; as it flew over the lake, its thermal images detected the heat signature of his 
hiding in the woods. ${ }^{43}$ Robots that are equipped with near-infrared lenses or sensors can detect sound outside the range of human ears, or identify trace elements of explosives or narcotics. ${ }^{44}$ Patrolling robots equipped with millimeter wave scanners similar to what the TSA uses at airports ${ }^{45}$ will be able to see underneath a person's clothing and identify what they are carrying in their pockets. ${ }^{46}$ And like the police robots in China and Dubai, ${ }^{47}$ police robots with facial recognition software will be able to look for a match between the individuals they encounter and the images in a database of individuals with outstanding warrants. ${ }^{48}$

Meanwhile, a robot's memory capacity is far more accurate and longlasting than human memories; everything that a police robot sees and hears will be recorded and stored, allowing for perfect recall for later investigations and trials. We are already seeing this benefit from the spread of police body

body below the ice. Police Use Thermal Imaging Drone to Find Ice Fisher's Body, CHANnEL 3000 (Jan. 25, 2017), https://www.channel3000.com/news/police-use-thermal-imagingdrone-to-find-ice-fishers-body/292377183 (last updated Dec. 27, 2019).

43 Sharon Cummings, Bossier Parish Sheriff's Office Uses Drone to Find Runaways, MYARKLAMISS.COM (Mar. 14, 2017), https://www.myarklamiss.com/news/local-news/bossier -parish-sheriffs-office-uses-drone-to-find-runaways/. As the sheriff in this case noted: "Having these drones is a priority.... [W]e have the ability to launch a drone and immediately locate people .... O Our next case might be finding a lost child, looking for an elderly person who has wandered off, or searching for an armed robbery suspect. We will be ready ... and we will find you." $I d$.

44 See Sinclair, supra note 6, at 32-33.

45 See, e.g., Jack Stewart, Super-Fast Airport Scanners Are Coming-Eventually, WIRED (Dec. 22, 2018), https://www.wired.com/story/super-fast-airport-scanners/ (describing scanners that "can 'see' through clothes, ignore skin, and red-flag suspicious shapes and objects").

46 Of course, human police officers could also be equipped with many of these devices, but they might be unwieldy or impractical for a human officer to carry, particularly for an officer on foot patrol. The constitutionality of using these surveillance devices is discussed infra at notes 115-120 and accompanying text.

47 See supra notes 31-34 and accompanying text.

48 Currently the United States has about 117 million people in facial recognition databases, and police use it to scan CCTV footage for suspects. Countries like China, Russia, and the United Kingdom have also experimented with using facial recognition technology for police surveillance. Under the best conditions, the best systems have an error rate of $0.2 \%$, but in the real world many are still not very accurate; a recent experiment in the United Kingdom resulted in 2,755 false positives out of 2,900 potential matches. Ian Sample, What Is Facial Recognition-And How Sinister Is It?, GuARDIAN (July 29, 2019), https://www.theguardian.com/technology/2019/jul/29/what-is-facial-recognition-and-howsinister-is-it. In order to create reasonable suspicion for a Terry stop, the technology would not have to be $100 \%$ accurate; as long as it could correctly identify fugitives around $30 \%$ of the time, it would probably satisfy the reasonable suspicion standard. See Ric Simmons, SMART Surveillance: How to InTERPRET the Fourth AMENDMENT IN THE TwENTY-FIRST CENTURY 73-83 (Cambridge Press 2019) (examining surveys of judges to determine the level of probability necessary to satisfy reasonable suspicion). 
cameras, ${ }^{49}$ and it will only accelerate as robot police officers become more numerous. ${ }^{50}$

Another less intuitive benefit of police robots is their flexibility. When substantive or procedural laws change, police officers need to be re-trained and sometimes need to learn new protocols and procedures (as well as unlearn others that they have been using for years or even decades). Police robots can simply be re-programmed to comply with the new rules. For example, if a jurisdiction legalizes marijuana, or a state supreme court changes the law on police conduct during seizures, human police officers may need time and practice to change their behaviors accordingly, while a robot can be updated to ensure it follows the new law right away. Or, on a more localized level, police robots can be designed or programmed to be as intrusive or as non-intrusive as a community wants them to be. If the local community wants to crack down on gun crimes or drug crimes, then the police could lease robots with enhanced surveillance capabilities to detect those specific types of contraband. Similarly, if a local community is less concerned about crime control and more concerned about privacy rights, the police department could program those same robots to not engage in advanced surveillance techniques.

A final benefit, which is also related to increased capability, is the durability and - to put it bluntly — expendability of police robots. Deploying a robot instead of a human police officer in potentially dangerous situations will enhance officer safety. Police departments have been using bombdisposal robots for decades in order to protect human police officers from the inherent dangers of those situations. ${ }^{51}$ As noted earlier, many of these bomb-disposal robots are also used for other purposes, allowing police to respond to locations and situations that would be inaccessible or dangerous for a human officer. ${ }^{52}$ For example, officers in La Crosse, Wisconsin were

49 See Stephen E. Henderson, Fourth Amendment Time Machines (and What They Might Say About Police Body Cameras), 18 U. PA. J. Const. L. 933, 964, 966-69 (2016).

50 A related benefit is that any police abuse or Fourth Amendment violations that are committed by robot police officers (usually by direction from their human pilots) will be recorded and stored for use as evidence against the police. See id. at 968-70.

51 These robots are relatively agile, usually with multiple sets of caterpillar tracks or six or more wheels. Peter Ray Allison, What Does a Bomb Disposal Robot Actually Do?, BBC FuTURE (July 15, 2016), http://www.bbc.com/future/story/20160714-what-does-a-bombdisposal-robot-actually-do. They are equipped with sophisticated cameras and arms so that the human operator can manipulate objects or pick them up and carry them. Kathy Marks, Robotics for Bomb Squads, TACTICAL RESPONSE (Jan./Feb. 2012), http://www.hendonpub.co $\mathrm{m} /$ resources/article_archive/results/details?id=1102 [https://web.archive.org/web/201710150 34530/www.hendonpub.com/resources/article_archive/results/details?id=1102].

52 Most robot policing devices that interact directly with the community focus on "intense" situations such as bomb detection and deployment or entry into structures with an active shooter. See April Glaser, 11 Police Robots Patrolling Around the World, WIRED (July 
executing an arrest warrant in a home and believed the suspect was hiding in the crawlspace. ${ }^{53}$ They sent their robot into the crawlspace and quickly located the man, who soon surrendered and emerged voluntarily when the police sent a drug dog in after him. ${ }^{54}$ Internationally, remote-control drones armed with pepper spray, tear gas, and paintballs are used for riot control, a job which is especially dangerous for human police officers. ${ }^{55}$

Even routine tasks like traffic stops have the potential to be dangerous or even deadly for human police officers and the civilian drivers that are pulled over. ${ }^{56}$ A new type of robot now in development deploys from an officer's police car after the officer pulls over a vehicle for a traffic infraction. ${ }^{57}$ The robot conducts the traffic stop remotely, allowing the officer to stay safely in his or her car and communicate with the driver through video phone, thus eliminating the danger of a violent confrontation that could result in injury or death to the officer or the driver. ${ }^{58}$

The potential disadvantages of widespread police robots are the flip side of the benefits. The greater efficiency of robots raises the possibility that the surveillance state will grow even more powerful, with cities purchasing hundreds of aerial drones and robot police officers to constantly

24, 2016), https://www.wired.com/2016/07/11-police-robots-patrolling-around-world; Mike Thomas, Police Robots: What They Are \& How They're Used, BuILT In (May 30, 2019), https://builtin.com/robotics/police-robot-law-enforcement; see also supra notes 18-21 and accompanying text.

53 See La Crosse Police Use Robot, K-9 Arrest Man Hiding in Crawl Space, News 8000 (Feb. 25, 2019), https://www.news8000.com/news/crime/la-crosse-police-k-9-arrest-manhiding-in-crawl-space/1039770684.

54 Id.

55 In India, police in the Uttar Pradash region purchased "Skunk drones," which can release tear gas and fire up to twenty paintballs per second. The drones also have bright strobe lights and lasers to help disperse crowds, speakers that allow police to communicate with the crowds, and a camera, a thermal camera, and microphone for surveillance. Glaser, supra note 52.

56 In 2015, over one hundred people were shot and killed by police after a traffic stop. Wesley Lowery, A Disproportionate Number of Black Victims in Fatal Traffic Stops, WASH. Post (Dec. 24, 2015), https://www.washingtonpost.com/national/a-disproportionate-numberof-black-victims-in-fatal-traffic-stops/2015/12/24/c29717e2-a344-11e5-9c4e-

be37f66848bb_story.html?noredirect=on\&utm_term $=.2 \mathrm{dfb} 79 \mathrm{bd} 938 \mathrm{~d}$. While in 2018, two police officers were killed while conducting traffic stops. FBI Releases 2018 Statistics on Law Enforcement Officers Killed in the Line of Duty, FBI (May 6, 2019), https://www.fbi.gov/news/pressrel/press-releases/fbi-releases-2018-statistics-on-lawenforcement-officers-killed-in-the-line-of-duty.

57 See Peter Holley, One Solution for Keeping Traffic Stops from Turning Violent: A Robot That Separates Police Officers from Drivers, WASH. Post (May 14, 2019), https://www.washingtonpost.com/technology/2019/05/14/one-solution-keeping-trafficstops-turning-violent-robot-that-separates-police-officersdrivers $/$ ?utm $\_$term $=.47 \mathrm{~b} 1 \mathrm{bba} 53 \mathrm{fc} 9$.

58 Id. 
patrol the skies and the streets. ${ }^{59}$ If current trends continue, this increased amount of surveillance will fall disproportionally on poor and minority populations, who live in so-called "high crime" neighborhoods, raise their families in public housing, and attend inner-city public schools. ${ }^{60}$ Furthermore, the formidable data collection and retention capabilities of police robots could imbue them with an unrealistic veneer of infallibility in the minds of judges and juries, who may not accurately evaluate the dangers of data manipulation and tampering that exist with any type of machinegenerated evidence. ${ }^{61}$

Finally, there is also an Orwellian feel to a world in which law enforcement robots patrol the street; such a development will create further distance, both literally and figuratively, between the human police and the neighborhoods they are policing. Judge Michael Sinclair notes that a robot police force will be ill-equipped to conduct community policing and other forms of human interaction, since "robots, remotely-operated or otherwise, will almost certainly be less capable than humans in this regard." $" 62$

\section{The Capabilities of Robot Police to Search, Seize, and Arrest Suspects}

Robot police not only face challenges in forging a personal connection with those that they encounter; they also have limited capabilities to physically interact with suspects. Aerial drones and bomb-disposal devices are not designed for that kind of work, and even the existing private security robots can do little more than approach a suspect to allow the human pilot to speak with him.

59 There is a parallel to the concern that people have over introducing machines to the military - if war becomes too cheap and involves less risk to human lives, there is less of a deterrent to going to war. Similarly, if robotic police officers make surveillance inexpensive and remove any risk of injury or death to police officers, there is a danger that the losing these natural checks and limits will result in over-surveillance by the police.

60 Professor Bennett Capers argues that the use of certain types of surveillance technology will actually equalize privacy costs felt by all Americans. See Bennett Capers, Race, Policing, and Technology, 95 N.C. L. Rev. 1241 (2017). This is probably true for the kinds of technology that he discusses in his article, such as public surveillance cameras, big data analysis, and gun detectors. Robot police officers certainly will deploy these tools. But if police departments are simply given the ability to double the number of police officers that they can deploy, it seems likely they will continue with their established resource allocation patterns.

61 In a more subtle way, the use of evidence gathered by police robots could change the way defense attorneys do their job; instead of building reasonable doubt based on crossexamining police officers and challenging the credibility of eyewitnesses, defense attorneys will be more likely to rely on experts to testify that the robot's detection devices were not properly calibrated or that the machine-collected data was not properly safeguarded after it was collected.

62 Sinclair, supra note 6, at 38. 
With today's technology, however, robot policer officers could be designed to conduct a Terry stop and even effectuate an arrest. ${ }^{63}$ In order to detain a suspect, a robot (or the human pilot controlling the robot) merely needs to order the suspect to stand still - if the suspect complies, the robot will have successfully conducted a Terry stop. ${ }^{64}$ Although the suspect could choose to ignore the command and flee from the robot officer, this will likely not happen very often; the suspect will know that his face has been captured and recorded by the robot's cameras, and he will be committing a crime simply by refusing to comply with a lawful order. ${ }^{65}$ Furthermore, the robot officer would follow the suspect and broadcast the location of the suspect to human police officers, and the suspect's face would be added to the database of individuals who are wanted for a crime. Thus, most suspects who disobeyed this order would eventually be caught and prosecuted. ${ }^{66}$

A robot designed with the ability to use non-lethal force could physically detain suspects, either to effectuate an arrest or to conduct a Terry stop. The robot could order the suspect to put his hands into restraints attached to the robot, and if a suspect refused to comply with a robot's order to stop or use the restraints, the robot could deploy devices such as pepper

63 Robots will also conduct searches when they are asked to execute search warrants or arrest warrants. Pursuant to a warrant, an aerial surveillance drone could be ordered to fly over a suspect's backyard to record what it sees. Pursuant to an arrest warrant, a remotecontrolled or semi-autonomous robot could be sent into a home to conduct an initial search or sweep before the officers enter-or to effectuate the entire arrest and escort the suspect out of the house if the suspect is cooperative.

As noted above, we are here only discussing semi-autonomous robots, which can perform some functions (such as routine patrol and identification of suspicious situations) on their own, but which would be controlled by a human pilot at the time of a search, detention, or use of force. Therefore, we are not concerned (at this time) with how a robot officer would decide on its own when to conduct a search, when to detain, or when to use force.

64 See California v. Hodari D., 499 U.S. 621 (1991) (submission to lawful authority constitutes a stop).

65 Failure to comply with an order to stop pursuant to Terry constitutes obstructing official business or a similar crime. See, e.g., State v. Newsome, No. 17CA2, 2017 WL 3912980, at *4 (Ohio Ct. App. Aug. 31, 2017) (fleeing from a Terry stop constitutes obstructing official business under OHIO Rev. Code AnN. § 2921.31); People v. Marlow, No. 315166, 2014 WL 2935946, at*3 (Mich. Ct. App. June 26, 2014) (failure to comply with lawful Terry command constitutes obstruction under Mich. COMP. LAws $\S 750.81 \mathrm{~d})$; C.E.L. v. State, 995 So.2d 558, 562 (Fl. Dist. Ct. App. 2008) (fleeing from police and ignoring a lawful command to stop constitutes obstructing justice).

66 This model of Terry stops - relying on lawful authority backed up by the threat of prosecution - would shift from a policing model based on physical compulsion to one based on legal compulsion. When combined with hundreds of robots patrolling the streets with cameras, as well as thousands of CCTV cameras in public places, it will represent a trade-off, in which we choose to live in a world where police officers almost never touch us, and violence between police and civilians becomes vanishingly small, but police almost always know who and where we are when we are out in public. The result would be an increase in physical security and autonomy but a decrease in privacy. 
spray or conducted electrical weapons to incapacitate the suspect until human police officers arrive.

Once the robot officer had successfully detained the suspect, it could question the suspect further (as part of a Terry stop), or, if the human pilot determined that probable cause existed, it could place the suspect under arrest or hold the suspect until a human officer arrived to place him under arrest. $^{67}$

Police robots could also conduct searches. A robot that conducted a traffic stop could, if the driver consents or the human pilot determines there is probable cause, look inside the interior of a car. These robots could also be designed with Breathalyzers to check blood alcohol levels. Patrol robots could also - as directed by their human pilots — order suspects to take actions that would reveal information. A robot conducting a Terry stop could order a suspect to turn out his pockets, open his jacket, or lift up his shirt. Robots could order suspects to open briefcases or backpacks, or if the suspect was uncooperative, the robot could use an appendage to physically open the container. $^{68}$ As noted above, the robots could also be equipped with millimeter wave scanners to obtain images of the items that the suspect is carrying underneath his clothes, inside his pockets, or within his bags. ${ }^{69}$

\section{How RoBot Police OFFICERS WILl ChANGE Fourth AMENDMENT DOCTRINE}

The conventional wisdom is that robot police officers will increase the efficiency of law enforcement agencies, but will also bring increased threats to our privacy. Professor Melanie Reid raises eight issues posed by robot police officers, including the fact that "[r]obots will intrude on citizens' right to privacy more often than human officers as they will have access to more third[-]party data in a shorter period of time," and "[r]obots will have less people skills and common sense than human officers, and it is unclear how they will handle tense situations."70 On the other hand, Professor Reid

67 A more sophisticated robot could actually grab onto a suspect and handcuff him, but current models of law enforcement robots do not have this capability.

68 For example, the AVATAR Extended Manipulator Arm, manufactured by RoboteX, can pick up small objects and open knob handle doors. Avatar Accessories, RоBOTEX, https://robotex.com/products/avatar-accessories (last visited Feb. 9, 2020).

69 See supra note 45 and accompanying text.

70 Melanie Reid, Rethinking the Fourth Amendment in the Age of Supercomputers, Artificial Intelligence, and Robots, 119 W. VA. L. REV. 863, 867-68 (2017). Professor Reid's eight issues are the following:

(1) Robots will be smarter, faster, and more efficient than human officers[;]

(2) Robots will intrude on citizens' right to privacy more often than human 
predicts that robot police officers will streamline the process of applying for a warrant, which will probably lead officers to seek warrants more oftenalthough even then she worries that warrants may not "serve the same integrity check on police if they are easier to draft, send to a judge, and approve electronically."71

But the increased efficiency and potential threats to privacy that Professor Reid discusses will come about with or without robot police officers. In fact, these developments are already occurring: modern human police officers use computers that can instantaneously access third-party data, and electronic search warrants are now common in many jurisdictions. ${ }^{72}$ And although modern surveillance technology, such as video cameras, thermal imagers, or backscatter scans do create new Fourth Amendment challenges, ${ }^{73}$ they are also not unique to robots, since human police officers are already using these technologies to varying degrees.

The unique aspect of robot police officers that profoundly changes the nature of police/civilian interactions is their ability to insulate human police officers from danger. As we will see below, this feature of robot police officers challenges the fundamental assumptions of two Fourth Amendment doctrines: the Terry line of cases that give police broad powers to conduct searches, and the rules governing police use of force.

officers as they will have access to more third[-]party data in a shorter period of time[;]

(3) Robot capabilities will require a complete rethinking of Fourth Amendment doctrine based upon the amount of information they will access on a daily basis[; ]

(4) Free-thinking robots will require human intervention and supervision[;]

(5) Robots and human officers may follow the same laws but use different standards to arrest people, i.e., inflexible programming versus discretion[;]

(6) Robots will have less people skills and common sense than human officers, and it is unclear how they will handle tense situations[;]

(7) The community will perceive robo-cops differently than human officers[; and]

(8) Robots should be treated identically to their human counterparts when it comes to law enforcement and the Fourth Amendment, e.g., motions to suppress evidence filed on the basis of a robot's action (or omission), or suspects filing abuse of civil rights claims against a robo-cop while in performance of its duties.

Id. at $867-68$.

71 Id. at 874.

72 See, e.g., H. Morley Swingle \& Lane P. Thomasson, Beam Me Up: Upgrading Search Warrants with Technology, 69 J. Mo. B. 16, 18-20 (2013) ("With e-mail, officers can get search warrants quickly without leaving the crime scene.").

73 See, e.g., Kyllo v. United States, 533 U.S. 27 (2001) (discussing the constitutionality of thermal imagers used on a home); Henderson, supra note 49, at 964, 966-68 (discussing the Fourth Amendment issues raised by police body cameras). 


\section{A. The Expansive Powers Granted by the "Officer Safety" Rationale}

\section{Terry v. Ohio}

In 1968, the United States Supreme Court revolutionized Fourth Amendment jurisprudence in Terry $v$. Ohio. ${ }^{74}$ Terry gives a police officer the right to forcibly detain an individual for a brief period of time if the officer has reasonable suspicion that the individual is involved in criminal activity. ${ }^{75}$ This "stop and inquire" power granted by Terry was the less controversial aspect of the opinion; even the defendant in Terry conceded that the police had to have some ability to investigate when they observed suspicious activity. ${ }^{76}$ The Terry Court could have stopped there, and allowed police to conduct a stop but no frisk; a police officer who had reasonable suspicion would order a suspect to stop, ask him some questions, and detain him for a minute or two without ever physically touching him. These stops would no doubt represent a significant inconvenience to the suspect, and many suspects would feel harassed by the police. But the degree of indignity and loss of privacy would be orders of magnitude less than it would be for those who are subjected to a frisk. ${ }^{77}$

74392 U.S. 1 (1968).

75 Id. at 24 ("When an officer is justified in believing that the individual whose suspicious behavior he is investigating at close range is armed and presently dangerous to the officer or to others, it would appear to be clearly unreasonable to deny the officer the power to take necessary measures to determine whether the person is in fact carrying a weapon and to neutralize the threat of physical harm.").

$76 I d$. at 25 ("Petitioner does not argue that a police officer should refrain from making any investigation of suspicious circumstances until such time as he has probable cause to make an arrest.").

77 The Terry Court acknowledged the serious intrusion caused by a frisk: "[I]t is simply fantastic to urge that such a procedure performed in public by a policeman while the citizen stands helpless, perhaps facing a wall with his hands raised, is a 'petty indignity.' It is a serious intrusion upon the sanctity of the person, which may inflict great indignity and arouse strong resentment, and it is not to be undertaken lightly." Id. at 16-17 (citations omitted); see also id. at 24-25. "Even a limited search of the outer clothing for weapons constitutes a severe, though brief, intrusion upon cherished personal security, and it must surely be an annoying, frightening, and perhaps humiliating experience." Id. The Terry Court makes no such declarations regarding the intrusiveness or humiliation of the stop aspect of the procedure.

The indignities suffered by subjects of a Terry frisk are well documented in more recent studies of the procedure. In a 2012 report, the Center for Constitutional Rights investigated the dramatic increase in Terry stops in New York City. While some of the societal and psychological damage caused by the practice was linked to the sheer number of stops and the evidence that the police were engaging in racial profiling, the majority of the harm caused by the procedure was linked to the frisking procedure. The report catalogues abuses of the frisk doctrine, including "being forcibly stripped to ... underclothes in public, inappropriate touching, physical violence and threats, extortion of sex, sexual harassment[,] and other humiliating and degrading treatment." See Stop and Frisk: The Human Impact, CTR. FOR CONST. RTS. 5 (July 2012), https://ccrjustice.org/sites/default/files/attach/2015/08/the- 
Of course, that is not the actual world we live in, because the second half of the Terry holding authorizes police to conduct a brief search incident to the stop. ${ }^{78}$ As the Terry Court recognized, the propriety of the frisk conducted by the police officer was the critical aspect of the case. ${ }^{79}$ But in approving of the frisk, the Court stated that the frisk itself is merely tangential to the stop. ${ }^{80}$ It is not part of the investigation that is based on reasonable suspicion; it is a necessary evil that is required so that the police officers can safely conduct the field interrogation, and (in theory) it is only allowed if the officer has "reason to believe that he is dealing with an armed and dangerous individual." 81 Thus, in a context where there is no concern for the protection of the police officer-for example, if there is no human police officer present at the stop - the justification for the Terry frisk disappears.

Under Terry, a police officer is only legally authorized to conduct a frisk if the officer reasonably believes a suspect is armed and poses a physical threat to the officer. ${ }^{82}$ But in the decades since Terry, courts have been extremely deferential to police officers who conduct Terry frisks. In some cases, the factors supporting the frisk seem reasonable: the police officer has reason to believe the suspect is planning a robbery, ${ }^{83}$ or the police officer received a tip that the individual was carrying a firearm. ${ }^{84}$ But in other cases, the courts treat the right to frisk as almost automatic following a legitimate stop. In Illinois $v$. Wardlow, for example, the police saw the suspect standing in an area known for heavy narcotics trafficking, and the

human-impact-report.pdf. Even when the police do not abuse their authority during a frisk, the touching and squeezing of the suspect's body which is authorized by Terry is a degrading experience that violates the suspect's bodily integrity.

78 Terry, 392 U.S at 27.

79 "The crux of this case, however, is not the propriety of Officer McFadden's taking steps to investigate petitioner's suspicious behavior, but rather, whether there was justification for McFadden's invasion of Terry's personal security by searching him for weapons in the course of that investigation." Id. at 23.

$80 I d$. at 26 ("An arrest is the initial stage of a criminal prosecution. It is intended to vindicate society's interest in having its laws obeyed, and it is inevitably accompanied by future interference with the individual's freedom of movement, whether or not trial or conviction ultimately follows. The protective search for weapons, on the other hand, constitutes a brief, though far from inconsiderable, intrusion upon the sanctity of the person.").

81 Id. This is a different and distinct standard than what is required to authorize a stop.

82 Id. at 27. ("Our evaluation of the proper balance that has to be struck in this type of case leads us to conclude that there must be a narrowly drawn authority to permit a reasonable search for weapons for the protection of the police officer, where he has reason to believe that he is dealing with an armed and dangerous individual, regardless of whether he has probable cause to arrest the individual for a crime.")

83 Id. at 27-28.

84 Adams v. Williams, 407 U.S. 143, 144-45 (1972). 
suspect fled when he saw the police. ${ }^{85}$ The police officer conducted a Terry stop and a frisk because "in his experience[,] it was common for there to be weapons in the near vicinity of narcotics transactions." 86 The Supreme Court explicitly upheld the stop after conducting an analysis of the factors that led to the officer's reasonable suspicion that the suspect was involved in criminal activity, but never discussed whether the officer had reason to believe the suspect was armed, thus implicitly approving of the frisk with no evidence of dangerousness. ${ }^{87}$

Lower courts have been even more willing to approve of frisks, and they have expanded the range of suspected crimes that give police officers an automatic right to frisk. ${ }^{88}$ Writing twenty-six years after Terry was decided, Professor David A. Harris reviewed hundreds of stop-and-frisk decisions by lower courts. ${ }^{89}$ He determined that many courts automatically allowed frisks for any narcotics trafficker, and some courts permitted an automatic frisk for the purchaser in a drug transaction. ${ }^{90}$ Many courts also often automatically approve of frisks of burglary suspects, on the theory that burglars "often carry screwdrivers and or other tools that they might use as weapons." "Some courts also automatically allow a frisk of any companion of an arrestee, any individual present when a search warrant is executed, any individual who is placed in a squad car during a Terry stop, and any time the police officers are outnumbered or in a high-crime area. ${ }^{92}$

It is also easy for police officers to characterize relatively innocuous behavior by the defendant as indicating the suspect is armed and dangerous, including moving his hands under his coat ${ }^{93}$ or appearing nervous when the

85528 U.S. 119, $121(2000)$.

86 Id. at 122.

87 Id. at $124-26$.

88 See David A. Harris, Frisking Every Suspect: The Withering of Terry, 28 U.C. DAVIS L. REV. 1, 22-23 (1994) ("Notwithstanding the Supreme Court's instructions, lower courts allow frisks automatically - categorically — in many situations in which the offense suspected does not require a weapon, and the suspect shows no outward sign he might be armed and dangerous.")

89 Id. at $22-32$.

$90 \quad I d$. at $25-26$.

$91 \quad I d$. at 27.

92 Id. at 28-32. Professor Harris concludes his overview of the lower court cases by noting that " $[\mathrm{m}]$ any . . . lower court decisions on frisks have moved toward one goal: allowing police to make more frisks by assuming that more and more crimes, persons, and situations could present danger to officers, when in fact they may not. The result has been a steady progression toward a point at which anyone, anytime, may be searched if they are stopped, with no limits on police discretion." Id. at 52.

93 In re D.E.W., 612 A.2d. 194, 195 (D.C. 1992). 
officer approaches. ${ }^{94}$ Professors Harris and David Rudovsky note that many of these factors are not in fact indicative of possession of a weapon:

The data show that certain factors regularly reported by police, such as observation of a "bulge," a suspect not being cooperative, a suspect having their hands in their pockets, presence in a highcrime neighborhood, acting nervous or making furtive movements, and "flight" are poor predictors of whether one is armed and dangerous, yet the courts have regularly credited these explanations in sustaining police frisks. In almost all cases, "'bulges' turn out to be cell phones or wallets," and the other triggering factors are also very weak indicators of criminal activity. Thus, in audits conducted in 2014-2016, of 220 frisks based on a "bulge," only one weapon was seized, a hit rate of less than $0.5 \% .^{95}$

These broad standards mean that in reality, many Terry stops are accompanied by frisks, although the number seems to vary widely from jurisdiction to jurisdiction. ${ }^{96}$

The open secret is that police officers routinely use Terry frisks as a way to search for evidence, or-more subversively - as a way to assert control and dominance over an individual or a neighborhood. ${ }^{97}$ The courts

94 State v. Matthew David S., 205 W.Va. 392, 396 (1999).

95 David Rudovsky \& David A. Harris, Terry Stops and Frisks: The Troubling Use of Common Sense in World of Empirical Data, 79 OHIO ST. L.J. 501, 541-42 (2018) (citations omitted).

96 For example, in New York City $66 \%$ of stops lead to frisks, while in Seattle only $21.8 \%$ of stops lead to frisks. See Stop-and-Frisk in the De Blasio Era (2019), NYCLU (Mar. 14, 2019), https://www.nyclu.org/en/publications/stop-and-frisk-de-blasio-era-2019; Seattle Police Dep't, Stops and Detentions Annual Report 6 (2018), https://www.seatt le.gov/Documents/Departments/Police/Reports/2017-Stops-and-Detentions-Final.pdf. In Boston, about $40 \%$ of stops lead to a frisk. JeFFery FAgAn eT AL., An ANALysis of RACE and Ethnicity Patterns in Boston Police Department Field Interrogations, OBSERVATION, FRISK, AND/OR SEARCH REPORTS 3 (June 15, 2015), https://s3.amazonaws.com /s3.documentcloud.org/documents/2158964/full-boston-police-analysis-on-race-and-ethnicit y.pdf. While Philadelphia, when operating under a consent decree, saw its frisk rate drop to $17 \%$ of all stops. Plaintiff's Fifth Report to Court and Monitor on Stop and Frisk Practices at 9, Bailey v. Philadelphia, (E.D. Pa. 2013) (No. 10-5952). These numbers are hard to come by; some cities refuse to collect data on their stop-and-frisk practices, while the collection practices of other cities have been strongly criticized as inaccurate. See NEAR Act Stop and Frisk Data Collection, ACLU (Mar. 28, 2018), https://www.acludc.org/en/news/near-actstop-frisk-data-collection; Becca James, Stop and Frisk in 4 Cities: The Importance of Open Police Data, SunLight Found. (Mar. 2, 2015), https://sunlightfoundation.com/2015/03/02/st op-and-frisk-in-4-cities-the-importance-of-open-police-data-2.

97 The class action litigation challenging the aggressive stop-and-frisk policies in New York City provided some colorful evidence that police use Terry stops and frisks to establish control and dominance in the neighborhood. For example, during a roll call in 2008, a police officer Lieutenant gave the following speech to his officers:

All right, I went out there [to Howard and Chauncey] yesterday and . . . we've 
have been complicit in this practice because they are reluctant to secondguess police officers who legitimately face real dangers in their jobs. On one level, this deference is understandable: judges will be disinclined to overrule an officer's decision in the field regarding physical safety, and no judge wants to set rules that make the police officer's job unreasonably dangerous. ${ }^{98}$ Furthermore, police officers have a specialized expertise in identifying dangerous individuals and dangerous situations; as the Supreme Court has noted: "the evidence thus collected [in support of reasonable suspicion] must be seen and weighed not in terms of library analysis by scholars, but as understood by those versed in the field of law enforcement." 99 But data suggests that police officers conduct frisks more often than the Terry standard should allow, since the hit rates for these frisks are extremely low. Over the course of the millions of frisks conducted by the NYPD in the early $2000 \mathrm{~s}$, only $1.5 \%$ of the frisks revealed a weapon; ${ }^{100}$

got the old man out there with the grey hairs. A loud mouth. He thinks since he's 55 years old he's not going to get locked up. Well, guess what? I don't tolerate shit out there. He went in and two of his pals went in. All right? So we've got to keep the corner clear.... Because if you get too big of a crowd there, you know ... they're going to think that they own the block. We own the block. They don't own the block, all right? They might live there but we own the block. All right? We own the streets here. You tell them what to do.

Floyd v. City of New York, 959 F. Supp. 2d 540, 597 (S.D.N.Y. 2013).

The Terry Court itself recognized that this was a danger when they initially authorized these searches back in 1968, quoting a report from a Presidential task force that noted that aggressive use of frisks during what was then known as "field interrogations" was inevitably "a severely exacerbating factor in police-community tensions." Terry v. Ohio, 392 U.S. 1, 14-15 n.11. The Court quoted further from the report: "This is particularly true in situations where the 'stop and frisk' of youths or minority group members is 'motivated by the officers' perceived need to maintain the power image of the beat officer, an aim sometimes accomplished by humiliating anyone who attempts to undermine police control of the streets." Id.

98 In Terry and in a number of subsequent cases interpreting Terry, the Supreme Court cites statistics about the number of police officers killed in the line of duty. See Terry, 392 U.S. at 24 n. 21 (noting that 57 law enforcement officers were killed in 1966, and 335 were killed in the seven-year period between 1960 and 1966); Adams v. Williams, 407 U.S. 143, 148 n.3 (1972) (noting that 125 policemen were murdered in 1971, with all but five of them killed by gunshots). Lower courts have also cited these statistics. See United States v. Micheletti, 13 F.3d 838, 844 (5th Cir. 1994) ("The number of police officers killed annually in the line of duty has tripled since Terry was decided; the numbers of those assaulted and wounded have risen by a factor of twenty"); State v. McGill, 609 N.W.2d 795, 801 (Wis. 2000) ("Although the number of officers killed in the line of duty has increased only slightly [since the Terry decision] (61 officers killed in 1998), the number of assaults on officers has more than doubled (59,545 line-of-duty assaults in 1998).”).

99 United States v. Cortez, 449 U.S. 411, 418 (1981).

100 Floyd, 959 F. Supp. at 558. 
likewise, between 2012-2016 the Philadelphia police found weapons in only $1 \%$ of their frisks. ${ }^{101}$

None of these critiques of Terry are new, of course, but solutions to this problem have been elusive. Occasionally, the Department of Justice or city residents will sue a city, arguing that the city's stop-and-frisk practices violate the residents' rights under the Fourth and Fourteenth Amendment. This tactic has had mixed success. A Philadelphia lawsuit led to a consent decree in 2011 in which a court monitored the police use of stop-and-frisk tactics. ${ }^{102}$ After four years, the court found that $56 \%$ of all frisks that occurred in 2015 lacked reasonable suspicion or occurred after a stop that lacked reasonable suspicion. ${ }^{103}$ In 2016, this number was only down to $41 \%$ of all frisks; ${ }^{104}$ by 2018 , it was still at $30 \%$ of all frisks. ${ }^{105}$ Sometimes the police react to these consent decrees with a "pullback"- a deliberate underenforcement of the criminal code, with disastrous results. ${ }^{106}$ In Baltimore, for example, prosecutors charged six officers with murder and related charges following the 2015 death of Freddie Gray in the back of a police van; in 2016, the city entered into a consent decree with the Department of Justice that, among other things, set new rules on the stop-and-frisk practices. ${ }^{107}$ Law enforcement officers responded by ceasing nearly all proactive policing activity, with predictable results: crime rose dramatically in the city, with homicides climbing from 197 in 2011 to 342 in 2017. ${ }^{108}$ A similar situation

101 See Rudovsky \& Harris, supra note 95, at 541 n.253 (2018) (citing Plaintiffs' Seventh Report to Court and Monitor on Stop and Frisk Practices: Fourth Amendment Issues at 19, Bailey v. City of Philadelphia (E.D. Pa. May 2, 2017) (No. 10-5952); Plaintiffs' Sixth Report to Court and Monitor on Stop and Frisk Practices: Fourth Amendment Issues at 19, Bailey v. City of Philadelphia (E.D. Pa. Mar. 22, 2016) (No. 10-5952); Plaintiffs' Fourth Report to Court and Monitor on Stop and Frisk Practices at 17, Bailey v. City of Philadelphia (E.D. Pa. Dec. 3, 2013) (No. 10-5952)).

102 Rudovsky \& Harris, supra note 95, at 536.

103 Id.

104 Id.

105 Plaintiffs' Ninth Report to Court and Monitor on Stop and Frisk Practices at 17, Bailey v. City of Philadelphia (E.D. Pa. Nov. 27, 2018) (No. 10-5952).

106 This phenomenon is also known as "depolicing," the "ACLU effect," or "the Ferguson effect."

107 Alec MacGillis, The Tragedy of Baltimore, N.Y. Times MAG. (March 12, 2019), https://www.nytimes.com/2019/03/12/magazine/baltimore-tragedy-crime.html.

${ }_{108} I d$. Baltimore police officers routinely reported that they believed the consent decree prevented them from effectively engaging with the community. One veteran police officer described the mixed messages he believed he was receiving: "Go out and stop crime, but don't hurt anyone's feelings," and "Be aggressive — but not too aggressive." Id. (internal quotation marks omitted). A survey of Baltimore police officers in 2019 said that $74 \%$ of officers felt "restricted" by the consent decree, and $43 \%$ did not feel comfortable making self-initiated arrests. One officer in the survey noted "[s]top-and-frisk was a very, very good tool in preventing shootings and other crimes. Bring the old style of policing back and let us do our job." Jayne Miller, Survey Finds Baltimore Police Officers Feel Restricted by Consent 
unfolded in Chicago, which entered into an agreement with the ACLU following the shooting of Laquan Donald. ${ }^{109}$ As a result, police stops plummeted from an average of around 60,000 per month in 2014-2015 to an average of around 10,000 per month in early $2016 .{ }^{110}$ At the same time, the homicide rate in Chicago skyrocketed from an annual average of between 400-500 homicides from 2007-2015 to 750 in 2016. ${ }^{111}$ Professors Paul Cassell and Richard Fowles conducted a regression analysis of the possible causes of this spike in homicides and concluded that there was a "very strong, statistically significant" link between the decline in stop-and-frisks and the increase in fatal and non-fatal shootings. ${ }^{112}$ Further analysis of seventeen cities showed that cities with consent decrees had violent crime rates that were $2.6 \%$ higher and property crime rates that were $6.9 \%$ higher than the national average. ${ }^{113}$

The Terry doctrine thus presents us with something of a paradox. On the one hand, police officers are routinely abusing the doctrine by conducting frisks in situations in which there is no reasonable suspicion that the suspect is armed, and courts, for the most part, are allowing them to do so. On the other hand, attempts to rein in the overuse of the frisk procedure are either ineffective or lead to pushback from the police, who believe that their safety is at risk if they are not given broad latitude to conduct frisks.

The introduction of robot police officers would immediately change the legal and practical landscape for Terry stops. The legal justification for frisks has always been based primarily on officer protection. A robot could conduct every aspect of a Terry stop-including the detention and the questioning that is necessary to confirm or allay the reasonable suspicion-

Decree, WBALTV (Feb. 15, 2019), https://www.wbaltv.com/article/consent-decree-policeofficer-survey/26361081.

Other cities have had more success with consent decrees. Chicago entered into an agreement with the ACLU following the shooting of Laquan Donald, and police stops plummeted from an average of around 60,000 per month in 2014-2015 to an average of around 10,000 per month in early 2016. See Shaila Dewan, Deconstructing the "Ferguson Effect," N.Y. TiMES (Mar. 29, 2017), https://www.nytimes.com/interactive/2017/us/politics/f erguson-effect.html.

109 Id.

$110 \quad I d$.

111 Paul S. Cassell \& Richard Fowles, What Caused the 2016 Chicago Homicide Spike? An Empirical Examination of the "ACLU Effect" and the Role of Stop and Frisks in Preventing Gun Violence, 2018 U. ILL. L. REV. 1581, 1586-87 (2018).

$112 I d$. at 1615.

113 Id. at 1612. The study did not include Chicago or New York. New York City appears to be a glaring exception to the depolicing effect: between 2011 and 2015, it saw a 95\% drop in stop-and-frisks as a result of class action litigation and a new policy put in place by a newly elected mayor, but this dramatic drop in stop-and-frisks coincided with a stable homicide rate. Id. at 1609 
without putting a human police officer in any danger, and thus without triggering the need for a frisk. Thus, under current doctrine, a robot would never be legally permitted to conduct a frisk during a Terry stop.

The repercussions of this could be far reaching. The most obvious result would be the elimination of frisks as part of the everyday interaction between police officers and suspects. This would reduce the level of privacy intrusion, intimidation, and humiliation that now often occurs with Terry stops. Not incidentally, it will also eliminate the danger that police officers legitimately fear when they conduct a Terry stop - the danger that led to the justification of frisks in the first place.

Another effect would be a dramatic decrease, if not outright elimination, of pretextual Terry stops. Police sometimes conduct a Terry stop not because they want to stop and inquire about potential criminal activity, but because they want to conduct a search for weapons or drugs. The reasonable suspicion standard is relatively low, and courts tend to be deferential to the expertise of police officers who use vague terms such as "furtive movement" or "looking nervous" to meet Terry's specific and articulable facts requirement. ${ }^{114}$ This creates an incentive for police officers to use Terry stops to search for drugs or weapons. Since robot police officers would not have that legal authority, police using these devices would be unlikely to waste their time stopping a suspect and asking him questions unless the officer truly believed the questions could uncover evidence of criminal activity.

Not only will the pretextual Terry stops decrease, the overall hit rate of the remaining stops will likely increase. This is true for two reasons. First, the human officers monitoring a robot's outputs will be able to conduct a much more thorough pre-stop investigation. Currently, if an officer sees a suspect make a suspicious movement-stuffing what might be a gun into his pocket, or handing over what might be a packet of drugs - the officer must rely on her split-second observation in order to decide whether reasonable suspicion exists. The human officers monitoring the robot officers will be able to replay the suspicious movement, slow it down, and enhance the image

114 See, e.g. United States v. Denney, 771 F.2d 318, 322 (7th Cir. 1985) (“The defendant's furtive gestures in moving or leaning toward the right side of the truck - a motion which the officers reasonably interpreted was consistent with reaching for a weapon - compounded the officers' belief that violence was imminent."); United States v. Gilliard, 847 F.2d 21, 25 (1st Cir. 1988) ("[The officers'] suspicion was based both on the place where the meeting between [the defendant] and the other individual took place ... and the unusual and furtive nature of the meeting."); United States v. Tillman, 543 F. App'x 557, 562-63 (6th Cir. 2013) (“[The defendant] disobeyed multiple commands to keep his hands visible, made two furtive movements, and was nervous. His conduct, when examined cumulatively, provides an adequate basis to find reasonable suspicion."). 
to get a much better view of what actually happened. They will also be in a position to use computers to cross-reference the incident with lots of other data - such as whether a known crack house is nearby, or whether the suspect has a prior criminal record for firearms possession. Thus, the human officer watching the monitors back at the precinct will have more information available to her, and will be able to build more evidence to support her reasonable suspicion than if she were in the field.

Second, as noted above, ${ }^{115}$ robot police officers have enhanced senses and will be able to detect the presence of contraband more easily and accurately than human police officers. Robot police officers with particle detectors could in theory scan everyone they see on the street and alert their human pilots whenever contraband is detected, which could then lead to the human pilot initiating a Terry stop.

Here, however, the police would need to be careful in how they designed the detectors on their robots. A robot that conducted a particle detector scan of an individual and sent the resulting image to its human monitor would be conducting a search without any individualized suspicion, since the human monitor would see an outline of everything the individual was carrying in his pockets and under his clothing. Instead, the robot would need to run the results of the scan through internal software that could identify the distinctive shape of a firearm or a vial of crack cocaine, and then convert that analysis to a binary result: the suspect either is or is not carrying contraband. If the former, the robot alerts its human pilot, who would be informed that the image detectors indicated a strong chance that the individual is carrying contraband, thus triggering the justification for a Terry stop. If the latter, the robot sends no message at all to its human monitor, and no human would know anything about the results of the scan. In neither case would a human being ever see the actual image detected by the robot, since the image would almost always contain information (e.g., images of non-contraband items) that was protected by the Fourth Amendment. Courts have routinely upheld binary searches such as this, including drug field tests ${ }^{116}$ and drug-sniffing dogs. ${ }^{117}$ These types of searches can only reveal the presence or absence of illegal activity, and individuals have no reasonable expectation of privacy to protect their illegal activity. ${ }^{118}$

115 See supra notes 42-48 and accompanying text.

116 United States v. Jacobsen, 466 U.S. 109, 121-22 (1984).

117 See Illinois v. Caballes, 543 U.S. 405, 410 (2005); United States v. Place, 462 U.S. 696, 707 (1983).

118 See Ric Simmons, The Two Unanswered Questions of Illinois v. Caballes: How to Make the World Safe for Binary Searches, 80 TuL. L. REv. 411, $448-59$ (2006). 
The good news is that it would be relatively easy, from a legal standpoint, for courts to hold that a police robot's scanning of civilians qualifies as a binary search in this context. One of the obstacles in designing binary searches is ensuring that the dog or device that is conducting the surveillance is accurate enough to create a sufficiently strong presumption that the individual is indeed committing a crime. ${ }^{119}$ This can be challenging when a binary search is used to justify a search warrant or a car search, since those actions require the police to have probable cause to believe contraband is present. ${ }^{120}$ In contrast, a robot police officer conducting a binary scan would only have to reach the lower standard of reasonable suspicion to justify a Terry stop. Thus, the software that attempted to identify the hidden items as contraband would not have to be as accurate as the canine sniffs that trigger probable cause searches - only accurate enough that it would give rise to a reasonable suspicion that the individual was carrying contraband.

Widespread deployment of these robots would mean that everyone in public would be scanned for contraband, and anyone who was carrying something that strongly resembled contraband would be approached by a robot (which would at that point be controlled by a human) and asked a few questions. This would be the equivalent of having drug dog on every street corner, unobtrusively sniffing everyone who passed by and barking to alert a nearby police officer if it detected contraband. The result would be more efficient law enforcement (fewer human police deployed, greater hit rates for Terry stops), but an increase in passive surveillance of individuals. ${ }^{121}$ None of this surveillance would reveal anything to the police other than whether someone was breaking the law, and most people would probably be unaware that they were even being surveilled.

To see how this would work in practice, consider the following hypothetical. Assume the police in an urban precinct deploy twenty robot police officers to a four-square-mile neighborhood. To support these robot

119 See Ric Simmons, Ending the Zero-Sum Game: How to Increase the Productivity of the Fourth Amendment, 36 HARV. J.L. \& Pub. POL'y 549, 581-83 (2013).

120 See Florida v. Harris, 568 U.S. 237, 243-45 (2013).

121 It is not clear whether this change would also involve an increase or decrease in the total number of Terry stops. On the one hand, pretextual Terry stops would become much more rare; as noted in the text, there will be no way for police to use an unjustified stop to justify a frisk. On the other hand, the greater sensory capabilities of robot police officers may generate legitimate reasonable suspicion more often, leading to more stops. Currently the hit rate for Terry stops - the rate at which actual contraband has been found following a Terry stop-has been measured at 3\% in Philadelphia and 14\% in New York. See Floyd v. City of New York, 959 F. Supp. 2d 540, 558 (S.D.N.Y. 2013); Plaintiffs' Fifth Report to Court and Monitor on Stop and Frisk Practices at 3, Bailey v. City of Philadelphia (E.D. Pa. 2013) (No. 10-5952). These are relatively low numbers, suggesting that if robots were only generating reasonable suspicion when there was a legitimate likelihood that a suspect was carrying contraband, there would not be a significant increase in the number of stops. 
officers, the police department employs two human officers in squad cars patrolling the area, as well as two officers back at the precinct monitoring everything the robots see as they patrol the area. The robot officers move randomly through the neighborhood, as human officers on foot patrol would have done, except the robots scan every person they see using millimeter wave scanners. The output of these scanners is fed into image recognition software, designed to identify illegal items. ${ }^{122}$ The software is set so that if the software detects a greater than $50 \%$ likelihood that an individual is carrying contraband, ${ }^{123}$ an alert goes off at the precinct, communicating to one of the monitoring officers that there is at least a reasonable suspicion that an individual within range is committing a crime. The robots also scan all of the faces that they see as they patrol and cross-reference the faces with images of individuals with outstanding warrants using facial recognition technology - again, if there is a greater than $50 \%$ chance that a match occurs, one of the human monitors will be alerted. The human monitors themselves are also watching the visual outputs of the robots' camera. If one of them sees behavior or an interaction that gives rise to reasonable suspicion-a

122 The illegal items would include packaging that is commonly associated with illegal drugs, such as small baggies or vials. It may also include firearms, if the robot is patrolling in a jurisdiction where firearms are illegal or where concealed carry permits are so hard to obtain that very few individuals are legally carrying guns. Alternatively, the robot could be equipped with a database with photos of everyone who owned a concealed-carry permit, so once a firearm is detected, the robot could instantly scan the person's face, compare it to the photos of legitimate gun owners, and only alert the human monitor if there was no match to a person with a permit.

123 The exact percentage could easily be altered, depending on where courts want to set the limit. Up until now, courts have been very reluctant — even hostile - towards the idea of quantifying what percentage chance establishes probable cause or reasonable suspicion, but given the predictive power of new surveillance technology, that will likely change. See Simmons, supra note 48, at 68-71. Lower courts have already (albeit grudgingly) approved specific numerical success rates for drug dogs as sufficient to establish that the dog's positive alert creates probable cause, holding that accuracy rates of between $50 \%$ and $60 \%, 50 \%, 55 \%$, $58 \%$, and $60 \%$ were all sufficient to satisfy the probable cause standard. See United States v. Anderson, 367 F. App'x 30, 33 (11th Cir. 2010) (approving a 55\% rate); United States v. Ludwig, 641 F.3d 1243, 1252 (10th Cir. 2011) (approving a 58\% rate); United States v. Donnelly, 475 F.3d 946, 955 (8th Cir. 2007) (approving a 50\% rate); United States v. Koon Chung Wu, 217 F. App'x 240, 246 (4th Cir. 2007) (approving a 60\% rate); see also United States v. Sanchez-Tamayo, No. 1:10-CR-0532-JOF-JFK, 2011 WL 7767740, at*14 (N.D. Ga. Nov. 28, 2011) (noting that courts have approved a drug dog reliability rate of "approximately 50\%-60\%" as sufficient to establish probable cause). But see United States v. Huerta, 247 F. Supp. 2d 902, 910 (S.D. Ohio 2002) (rejecting probable cause finding even though the drug dog had a $65 \%$ success rate). These cases were all determining what percentage chance would be required to achieve probable cause; for a Terry stop, the police would only have to establish the lower standard of reasonable suspicion, so $50 \%$ would almost certainly be sufficient. Wherever the percentage is set, it will take into account the error rate of the scanning device and the identification software, which (as with drug dogs) will be known quantities. 
person attempting to break into a locked car or the window of a residence, or an exchange that resembles a drug sale - she can take control of the robot to investigate further. Anything that a human officer on actual patrol might observe that leads to reasonable suspicion would also be grounds for the human officer who is monitoring the robot patrol from afar.

Whether the reasonable suspicion is triggered by the robot's algorithms, or by the human officer's own observations, the next step would be for the human monitor to take control of the robot and approach the suspect. The human officer then speaks through robot, ordering the suspect to stop. If the suspect ignores the command or tries to leave the scene, the human officer would have the option of compelling the suspect to submit to the stop, whether through ordering the robot to grab the suspect or by using other nondeadly force. If the suspect flees the encounter, his photo can be broadcast to all of the other robots in the area, as well as to the human officers on patrol.

If the detention is successful, the human officer begins to ask the suspect questions to confirm or dispel the suspicion. Presumably the questioning will focus on the reason for the stop, such as: "It appears you have an item that may be contraband, in your right front pocket; can you tell me what you are carrying?" or "What were you doing inside that abandoned building?" or "Do you know the owner of that car?" The robots would not be authorized to carry out any type of frisk or search; thus, the police officer's investigation would be limited to the questions and answers from the conversation.

If the human officer controlling the robot is able to develop probable cause through this investigation, she informs the suspect that he is under arrest and orders him to stay where he is until a human officer arrives to take custody of the suspect. At this point the robot officer would be legally allowed to conduct a search, both under the search incident to lawful arrest doctrine and in order to protect the safety of the approaching human officer. As we will see, however, this search power may also be limited by the courts, though not to nearly the same degree as the Terry frisk.

\section{Search Incident to Lawful Arrest}

In order to effectuate an arrest, a robot police officer would need to be able to detain a suspect for a prolonged period of time. ${ }^{124}$ As with Terry stops, a robot police officer could accomplish this through legal compulsion alone, though this may be more difficult to do for an arrest than for a Terry stop. A robot could be equipped with handcuffs or plastic constraints that it could attach to the arrestee's wrists if the arrestee cooperated. Some

124 See Florida v. Royer, 460 U.S. 491 (1983) (describing the legal difference between a stop and an arrest). 
arrestees would cooperate, given the fact that the alternative would be an obstruction of justice charge and/or the arrival of a human police officer to physically manhandle the arrestee into handcuffs. More sophisticated robots would also be able to employ non-deadly force to ensure compliance.

It is likely that police departments will want to use robots to conduct arrests whenever it is feasible to do so. Once the robot develops probable cause after a Terry stop or based on observations that it (and its human monitors) make while on patrol, it would be far more effective and safer if the robot could then arrest, search, and secure the defendant without having to wait for a human officer to arrive and put herself in danger. ${ }^{125}$ If police are executing an arrest warrant in someone's home, it would be safer for the police to wait outside and send in a robot to search for the defendant, inform him that he is under arrest, secure him, search him, and then lead him out of the home in handcuffs to the waiting officers. And because the robot officers would not be equipped to use deadly force and their human pilots would have little need or inclination to use non-deadly force to protect themselves, robot arrests would be safer for the arrestees as well.

Once the robot officer has conducted the arrest, it will have the right to conduct a search incident to that arrest. Depending on the technology available, the robot officer might conduct a crude sort of pat-down, order the suspect to reveal the items in his pockets, and/or conduct a scan of the suspect and transmit the actual images of the scan to the human monitor so that she can evaluate for herself if the suspect is carrying anything dangerous. The robot officer could also handcuff the suspect to ensure the safety of the human officer, or order the suspect to put his hands on his head or even to lie flat on the ground if there was reason to believe he was armed and dangerous.

As with Terry stops, officer safety is a key component of the search incident to a lawful arrest doctrine; thus, when robot police officers make an arrest, their powers to search will also be curtailed. The legal shift will likely be more subtle in this area than it is for Terry stops, for a number of reasons. First, a suspect who is being arrested will be brought to the police precinct, where he will inevitably be interacting with human police officers (and fellow arrestees); thus, the need to protect officer safety still exists even if a robot officer conducts the arrest. Second, unlike Terry frisks, which are only permitted for officer safety, a search incident to lawful arrest is justified both on the grounds of officer safety and to prevent the suspect from destroying

125 In the near future, a robot officer would conduct the arrest and then escort the defendant to a self-driving police car, so that no human officer would have to interact with the arrestee until the car pulled up to the police precinct. 
evidence. ${ }^{126}$ And third, the Supreme Court held in United States v. Robinson that the police power to conduct a search incident to lawful arrest doctrine is automatic - thus in theory it no longer relies upon the original justifications of officer safety and preservation of evidence. ${ }^{127}$

Even so, some aspects of the search incident to lawful arrest doctrine may be adjusted when a robot police officer makes the arrest. We have already seen one new technology - the cell phone-lead the Supreme Court to back away from Robinson's automatic right to search doctrine and resurrect the original justifications of the rule and limiting the doctrine in certain circumstances. ${ }^{128}$ It is entirely possible that another new technology - robot police officers conducting arrests-will also lead the courts to reconsider the justifications and scope of the rule.

The search incident to lawful arrest rule has been around for over a century, ${ }^{129}$ and it has evolved significantly during that time. The rule originally existed so that police could ensure that the defendant could not access any weapons that might endanger the police officers or help him escape custody, and to enable the officers to seize any contraband or evidence from the defendant's person so that he could not dispose of it or destroy it. ${ }^{130}$ These limitations led the Supreme Court to limit the geographic scope of the search to the defendant himself, any containers he was carrying, and the physical space around the defendant. ${ }^{131}$ This last area is known as the defendant's "wingspan" and comprises of any area that the defendant could reach at the time of the arrest. ${ }^{132}$

But these justifications - and any limitations based on these limitations - disappeared in 1973 in United States v. Robinson, the highwater mark for the search incident to arrest power. ${ }^{133}$ In Robinson, the defendant was arrested for driving with a revoked driver's license, and during a search incident to that arrest, the officer recovered a crumpled cigarette package from the defendant's shirt pocket. ${ }^{134}$ Although the package could not possibly contain any weapon or evidence of the crime he was

126 Chimel v. United States, 395 U.S. 752,763 (1968).

127 United States v. Robinson, 414 U.S. 218, 234-35 (1973) ("But quite apart from these distinctions, our more fundamental disagreement with the Court of Appeals arises from its suggestion that there must be litigated in each case the issue of whether or not there was present one of the reasons supporting the authority for a search of the person incident to a lawful arrest.").

128 See Riley v. California, 573 U.S. 373, 401 (2014).

129 Weeks v. United States, 232 U.S. 383, 392 (1914).

130 See Preston v. United States, 376 U.S. 364, 367 (1964); Chimel, 395 U.S. at 762-63.

131 Chimel, 395 U.S. at 763.

132 Id.

133414 U.S. 218 (1973).

134 Id. at 220-223. 
arrested for, driving with a revoked license, the officer opened the package, revealing heroin. ${ }^{135}$ The Supreme Court upheld the legality of the search, stating that "the fact of the lawful arrest [alone] establishes the authority to search." 136

But two more recent cases have limited the scope of these searches by resurrecting the original justifications for the rule. The first was Arizona $v$. Gant, in which the defendant drove up to his home, exited his car, and then was arrested a few feet away. ${ }^{137}$ The police handcuffed the defendant, placed him in the back of a police cruiser, and then searched his car. ${ }^{138}$ The Supreme Court found the search unconstitutional, noting that the defendant was handcuffed and secured, and so at the time of the search there was no danger of him reaching into the car to retrieve a weapon or destroy evidence. ${ }^{139}$ Thus, under Gant police have no right to search a car incident to an arrest unless the defendant is "unsecured and within reaching distance of the passenger compartment at the time of the search." 140 Five years later, the Supreme Court decided the case of Riley v. California, in which the police officers looked through the defendant's smartphone after stopping him "for driving with expired registration tags." 141 The Court once again returned to the original justification for the search incident to lawful arrest doctrine, noting that there is no way the contents of the cell phone could pose a danger to the officer and that the police could avoid destruction of evidence by turning the phone off or placing it inside a special bag that prevented it from receiving remote signals. ${ }^{142}$ The Court further found that the privacy interest for smartphones was much higher than for other types of containers, and so there was a greater reason to limit the doctrine in this context. ${ }^{143}$

Given this trend, the courts should take a fresh look at the search incident to lawful arrest doctrine when it is applied to robot police officers. As noted in the Terry discussion above, when a robot officer performs an arrest, there is no immediate worry that the suspect will cause physical harm to a human police officer. The defendant's person still needs to be searched

135 Id. at 223

136 Id. at 235.

137556 U.S. 332,336 (2009).

138 Id.

139 Id. at 351 ("Police may search a vehicle incident to a recent occupant's arrest only if the arrestee is within reaching distance of the passenger compartment at the time of the search or it is reasonable to believe the vehicle contains evidence of the offense of arrest. When these justifications are absent, a search of an arrestee's vehicle will be unreasonable unless police obtain a warrant or show that another exception to the warrant requirement applies."').

$140 \quad$ Id. at 343.

141573 U.S. 373, 378 (2014).

142 Id. at 387-91.

143 Id. at $391-98$. 
for weapons, but the risk that he would be able to grab a weapon within his wingspan and use it to harm the robot officer as it was making an arrest carries no legal weight, because the arresting officer is property rather than a human being. Thus, the rationale for searching the defendant's wingspan would be weakened, since the only remaining justification for such a search would be to ensure that the defendant did not grab and destroy evidence that was nearby. But the logic of Gant argues against this justification - the first thing a robot officer would do would be to handcuff the defendant, meaning that the defendant would have no way of reaching out to grab any kind of evidence or contraband. Thus, using robot police officers could signal the end of the "wingspan" rule.

A related rule that is almost certain not to apply to robot arrests is the "protective sweep" permitted under the Maryland v. Buie doctrine. ${ }^{144}$ Under this rule, when the police enter a home to effectuate an arrest (or for any other legal reason), and they have reason to believe that particular areas of the home may be harboring individuals who pose a threat to the arresting officers, the police can perform a cursory visual inspection of any of those areas where an individual may be hiding. ${ }^{145}$ Since the justification for protective sweeps lies solely in the risk of harm to human police officers, the legal power to conduct such a sweep disappears if there is no human police officer inside the house conducting the arrest. A robot police officer who was sent into a home pursuant to an arrest warrant would only be allowed to search for the arrestee, secure him and search him, and then immediately leave the home without looking through any other rooms.

Similarly, the doctrine of Michigan v. Long ${ }^{146}$ would not apply to robot police officers who conduct traffic stops. Under Long, when a police officer pulls over a vehicle and has reasonable suspicion that the suspect is dangerous and may try to grab a weapon, the officer may search through any areas of the passenger compartment of the vehicle that could potentially hold a weapon. ${ }^{147}$ In many contexts, this allows police to conduct a thorough search of a vehicle after it is pulled over based only on a reasonable belief that the vehicle may contain a weapon. If, however, the traffic stop is conducted by a robot police officer, there is no justification for a Long "frisk" of the automobile.

\footnotetext{
144 See Maryland v. Buie, 494 U.S. 325 (1990).

145 Id. at $334-35$.

146463 U.S. 1032 (1983).

147 Id. at 1049.
} 


\section{B. Use-of-Force Situations}

The potential for robot police officers to use force against suspects raises two separate questions. First, will widespread deployment of robot police officers result in more or less use of force by law enforcement? And second, when evaluating the propriety of police actions, will courts treat the use of force by robot police officers differently than use of force by human police officers? These are two separate questions, but they are related in a feedback loop: the less necessity there is for robots to use force, the less reasonable it will be for them to do so under the law, and the less reasonable it is for them to use force under the law, the less likely they are to actually do so.

The American Civil Liberties Union argues that allowing police robots to use force will result in more force being used against suspects, since it will be "easier" to use force with a robot and police officers will have "poor[er] situational awareness" when they act through a machine because the cameras on the robots will not give the police a true sense of how a situation may be developing. ${ }^{148}$ On the other hand, police officers acting through robots will feel less fear and stress when confronting a potentially dangerous suspect, and so will be less likely to act unreasonably in using unnecessary force.

The number and severity of use-of-force instances with robot police will also depend on how the robot is armed. Police robots can be equipped with numerous non-lethal force tools, such as a grabbing arm, pepper spray, tear gas, or a conducted energy device (otherwise known as a CED or Taser). ${ }^{149}$ As demonstrated by the 2016 Dallas incident, it is even feasible

148 E.B. Boyd, Is Police Use of Force About to Get Worse-With Robots?, Politico (Sept. 22, 2016), https://www.politico.com/magazine/story/2016/09/police-robots-ethics-debate214273. Rick Nelson, a fellow at the Center for Strategic and International Studies and a former counterterrorism official on the National Security Council, agrees, noting " $[t] h e$ further we remove the officer from the use of force and the consequences that come with it, the easier it becomes to use that tactic .... It's what we have done with drones in warfare." Fountain \& Schmidt, supra note 4.

149 In 2014, Albuquerque police used a robot to "deploy chemical munitions" against a man who had barricaded himself in a motel room with a gun, leading to his surrender. Fountain \& Schmidt, supra note 4.

Although giving police robots multiple tools of non-lethal force might make them less palatable to the community being policed, the empirical evidence from human police officers shows that increasing the options that a police officer has for non-lethal force tends to decrease the total number of injuries to suspects. A study of twelve large law enforcement agencies in 2010 concluded that use of pepper spray and Tasers decreased the likelihood of injuries to suspects by $65 \%$ and $70 \%$, respectively. See Philip Bulman, Police Use of Force: The Impact of Less-Lethal Weapons and Tactics, NIJ Journal No. 267 (Mar. 2, 2011), https://www.nij.gov/journals/267/pages/use-of-force.aspx. A similar study of the police departments in Austin and Orlando concluded that after CEDs were introduced to the police force, injury rates for both suspects and police forces dropped substantially. Id. The number of use-of-force cases increased in Orlando but decreased in Austin. Id. 
to equip a robot with the capacity to use deadly force. ${ }^{150}$ But as we will see below, it probably will not make sense to routinely equip police robots with this capability, because legally they will almost never be allowed to use it.

From a legal perspective, courts will need to tighten the use-of-force rules for robot officers. ${ }^{151}$ Under current law, police use of force is considered to be a type of "seizure" under the Fourth Amendment, and so it is legally justified only if it is objectively reasonable. ${ }^{152}$ This means police officers are generally permitted to use force if the suspect poses an immediate threat to the safety of the officer or others, or if he is actively resisting arrest or attempting to evade arrest by fleeing. ${ }^{153}$ The Supreme Court has held that reasonableness is determined "from the perspective of a reasonable officer on the scene, rather than with the 20/20 vision of hindsight." 154 In evaluating reasonableness, the Court has noted that "police officers are often forced to make split-second judgments-in circumstances that are tense, uncertain, and rapidly evolving" with respect to the amount of force needed in a given situation. ${ }^{155}$

Thus, just like the rules surrounding Terry frisks, rules surrounding police use of force are tied closely to the danger that the suspect poses to the (human) police officer in the scenario. If the suspect only presents a physical danger to a robot, courts will be less willing to certify police use of force as "reasonable." 156 Furthermore, police officers who are safe and far removed from the scene are less likely to feel the tension, pressure, and fear of the

150 See Fountain \& Schmidt, supra note 4.

151 Some disagree with this assertion; for example, the chairman of the National Tactical Officers Association notes that use-of-force laws apply to police regardless of what tool they use, arguing that "[t]he mechanism of how the force is delivered is irrelevant to the courts." Boyd, supra note 148

152 See Graham v. Connor, 490 U.S. 386, 396 (1989). Most states impose the same standard as the federal courts; see, e.g., Ala. CodE § 13A-3-27 (2014); AlaSKa Stat. AnN. $\S 11.81 .370$ (West 1978); Cal. Penal Code $§ 835 a$ (West 2020); Fla. Stat. AnN. $§ 776.05$ (West 2018); 720 Ill. Comp. Stat. AnN. § 5/7-5 (West 2012); Ind. CodE. AnN. § 35-41-3-3 (West 2018); Kan. Stat. Ann. § 21-5227 (2012); Me. Rev. Stat. Ann. tit. 17-A, § 107 (2007); Neb. Rev. Stat. ANN. § 28-1412 (West 1979); N.J. Stat. AnN. § 2C:3-7 (West 2019); N.Y. Penal Law $§ 35.30$ (McKinney 2004); Or. Rev. Stat. AnN. § 161.235 (West 2018); 18 Pa. Stat. and Cons. Stat. AnN. § 508(a) (West 2007); Tenn. Code Ann. § 40-7-108 (2018); Tex. Penal Code AnN. $\$ 9.51$ (West 2007).

153 Graham, 490 U.S. at 396.

154 Id

155 Id

156 Other effects that robot police may have on use-of-force incidents are harder to predict. For example, suspects may be more likely to try to evade arrest when confronted by a robot than by a human police officer, either because they will have less respect for the authority asserted by a machine than by a person, or because they believe they will have a better chance of escaping. If suspects tend to flee more often when lawfully detained or arrested by a robot, police will have to resort to force more often. 
uncertain and rapidly evolving situation, which means that courts will hold police to a higher standard. ${ }^{157}$

At the very least, the safety of the human pilot will mean that deadly force will almost never be legally justified. The Dallas incident was unusual in that the police were confronted with an armed man who had already killed five police officers and represented an ongoing threat; in that context, lethal force was arguably necessary to protect the public. ${ }^{158}$ But in the vast majority of cases, a robot police officer will not have the legal right to use deadly force, and any robotic use of force which did result in death would be much more likely to result in legal liability for the human pilot and the police department. ${ }^{159}$

Recent history has shown that human police mis-use deadly force all too often when they believe - sometimes mistakenly - that their lives are in danger. Police officers rarely face legal consequences for these actions, either because the prosecutor decides not to press charges or because a judge, jury, or grand jury determines that given the potential threat to their lives, they were legally justified in their actions. ${ }^{160}$ In most of these situations, a

157 A further deterrent to robot police officers using force is the possibility that civil liability for robot harm could be much higher than for when human officers cause harm, both because juries will be less likely to see the force as reasonable, and because juries might show more sympathy for a scared, human police officer making a split-second decision with her life on the line than for a human officer miles away in safety operating a large violent machine that causes harm to a civilian.

158 See Fountain \& Schmidt, supra note 4.

159 Courts will also have to explore whether the manufacturer of the robot or the programmer of the software could face liability if a robot malfunction leads to an improper use of force.

160 Police are often not prosecuted at all for lethal use of force, either because the prosecutor decides not to press charges, or the grand jury refuses to indict. When prosecutions do occur, convictions of police officers are extremely rare - of over 3,000 criminal cases brought against police officers between April 2009 and December 2010, only 33\% were convicted - about half the conviction rate compared to criminal cases overall. German Lopez, Stephon Clark Police Shooting in Sacramento: Autopsy Released, Vox (May 2, 2018), https://www.vox.com/identities/2018/3/22/17151960/stephon-clark-sacramento-policeshooting-video. A quick review of some of the more recent high-profile police shooting cases of unarmed civilians demonstrates this point - from Stephon Clark, who was fatally shot in his grandparents' backyard in Sacramento when he held up an iPhone, to Tamir Rice, a twelve-year-old who was fatally shot when playing with a realistic toy gun in a public park in Cleveland, to Michael Brown, who was fatally shot by police when he allegedly charged a police officer in Ferguson, Missouri. See id.; Eric Heisig, Tamir Rice Shooting: A Breakdown of the Events That Led to the 12-Year-Old's Death, Cleveland.Com (Jan. 13, 2017), https://www.cleveland.com/court-justice/2017/01/tamir_rice_shooting_a_breakdow.html;

Larry Buchanan et al., What Happened in Ferguson?, N.Y. TIMES (Aug. 10, 2015), https://www.nytimes.com/interactive/2014/08/13/us/ferguson-missouri-town-under-siegeafter-police-shooting.html. In each of these cases, a human pilot would almost certainly not have ordered the robot police officer to respond with deadly force, since there would be no imminent danger to any human at the time of the confrontation. 
human pilot controlling a robot police officer from a safe distance would not feel the need to use deadly force - and if she did, the use of force would certainly be held to be illegal. Even in a case where the suspect was actually armed with a deadly weapon, whether it is a car or a knife or a gun, a robot police officer would almost never need to use-nor be legally justified in using-deadly force. ${ }^{161}$

\section{HYDRAULIC PRESSURES AND EQUILIBRIUM ADJUSTERS}

The Terry Court acknowledged that police officers needed to be able to flexibly respond to the "rapidly unfolding and often dangerous situations on city streets." 162 The lone Terry dissenter, Justice Douglas, saw the case differently; he noted that " $[\mathrm{t}]$ here have been powerful hydraulic pressures throughout our history that bear heavily on the Court to water down constitutional guarantees and give the police the upper hand." ${ }^{163}$ In other words, when society, technology, or the substantive law shift to create more privacy, the shift often results in changes in procedural law or police practice to increase the power of the police to conduct surveillance. ${ }^{164}$ These hydraulic pressures can go both ways, as captured by Orin Kerr's equilibrium adjustment theory. ${ }^{165}$ As Professor Kerr noted, when police deploy new surveillance tools like thermal imaging devices, GPS devices, and sense-

161 See, e.g., Aaron Morrison, Albany Police Shot a Teen in the Back and Paralyzed Him. The D.A. Said It Was Justified., APPEAL (Mar. 22, 2019), https://theappeal.org/albany-policeshot-a-teen-in-the-back-and-paralyzed-him-the-da-said-it-was-justified/ (officer shot a nineteen-year-old who allegedly ran at him with a hunting knife); Kelly Fisher, Police Shooting of Beth Plant-Mother of Boxer Caleb Plant-Deemed "Justified," District AG Says, NASHVILlE TeNNESSEAN (Mar. 22, 2019), https://www.tennessean.com/story/news/loc al/cheatham/2019/03/22/cheatham-county-police-shooting-beth-plant-justified/3252447002/ (officer fatally shot a woman who allegedly brandished a knife at him); Officials: No Charges Filed Against Officer That Shot at Suspect's Car, News CHANnel 20 (July 3, 2019), https://newschannel20.com/news/local/officials-charges-will-not-be-filed-against-officerinvolved-in-shooting (officer shot a suspect when he ordered the suspect to get out of his vehicle but the suspect started to drive toward him, causing the officer to believe he was going to be run over; no charges were filed against the officer).

162 Terry v. Ohio, 392 U.S. 1, 10 (1968).

163 Id. at 39 (Douglas, J., dissenting).

164 The Terry decision itself, which expanded police procedural powers, was decided during the same time period that courts across the country were limiting the power of the police by striking down overly vague vagrancy and loitering laws. See, e.g., Papachristou v. City of Jacksonville, 405 U.S. 156, 170 (1972) (following the trend of striking down overly vague vagrancy laws). Thus, Terry's expansion of police powers could be interpreted as a way to give back to police the power to confront suspicious individuals that they used to possess when enforcing the vagrancy laws.

165 See Orin S. Kerr, An Equilibrium Adjustment Theory of the Fourth Amendment, 125 HARV. L. REV. 476 (2011). 
enhancing devices, the courts often adjust Fourth Amendment doctrine to increase privacy rights. ${ }^{166}$

How will this phenomenon play out in the context of robot police officers? On the one hand, robots will act as a force multiplier, allowing the police to place far more "officers" in the field for the same cost. Furthermore, robot police officers will have greater surveillance capabilities, thus decreasing the privacy of citizens even further. Privacy advocates have reacted with alarm to the prospect of widespread robot police; for example, the Executive Director of the Electronic Privacy Information Center has said that this development would "open[] the door to pervasive surveillance in public spaces .... Robots will capture all of the activity around them-not only the guy who is acting suspiciously, but also the young couple holding hands or a guy just walking down the street."167

Under this theory, the amount of police surveillance was originally bounded by limited police resources; when those limits are removed, the courts must step in to impose greater legal restrictions to return the amount of surveillance to the status quo ante. The Supreme Court is sympathetic to this claim that greater efficiency in law enforcement surveillance requires heightened Fourth Amendment protection. In United States v. Jones, ${ }^{168}$ the Court considered the constitutionality of continuous monitoring of a car's movements along public highways for a four-week period. Precedent had established that monitoring a car's movements on public highways was not a search, ${ }^{169}$ but a four-Justice concurrence in Jones argued that technological advances mandated an exception to that rule. ${ }^{170}$ In the pre-digital era, the concurrence pointed out, continuous twenty-four-hour surveillance of a person's public movements was possible, but it was "difficult and costly and therefore rarely undertaken." 171 Because of this practical difficulty, law enforcement officers were usually discouraged from engaging in dragnetstyle public surveillance. Now that GPS technology has made this type of surveillance possible, it would be feasible for law enforcement agencies to observe and record nearly every action civilians take in public, which would violate their reasonable expectation of privacy. Therefore, the Court had to change the law to limit the police power to conduct this type of surveillance.

\footnotetext{
166 Id. at 496-502. The most recent example of this reverse hydraulic pressure is Carpenter v. United States, 138 S. Ct. 2206 (2018). See infra note 172.

167 See Li, supra note 29 (internal quotation marks omitted).

168 565 U.S. 400 (2012).

169 United States v. Knotts, 460 U.S. 276 (1983).

170 Jones, 565 U.S. at 418-431.

171 Id. at 429 (Alito, J., concurring).
} 
Most recently, in Carpenter v. United States, ${ }^{172}$ the Court addressed the government's increased technological ability to monitor suspects' locations through cell site location information (CSLI). ${ }^{173}$ This improved surveillance capacity led the Supreme Court to expand the mosaic theory and create an exception to the third-party doctrine, thus increasing Fourth Amendment protections in response to the government's greater surveillance capacity. ${ }^{174}$ As the Court noted:

In the past, attempts to reconstruct a person's movements were limited by a dearth of records and the frailties of recollection. With access to CSLI, the Government can now travel back in time to retrace a person's whereabouts, subject only to the retention polices of the wireless carriers, which currently maintain records for up to five years. ${ }^{175}$

Thus, if robot police dramatically increase the government's ability to conduct surveillance in public areas, the courts may feel the need to strengthen Fourth Amendment protections, probably by broadening the mosaic doctrine, to restrict what types of public surveillance police are allowed to conduct without a warrant.

On the other hand, the use of robot police officers will also increase privacy in some ways, because there will be fewer pretextual Terry stops and far fewer frisks. Police rely on Terry frisks to find drugs and weapons; many police argue that the procedure is a critical tool in keeping guns off the streets. ${ }^{176}$ If this power is taken away from the police, how will the courts and law enforcement respond?

172138 S. Ct. 2206 (2018)

173 Id. at 2211.

174 Id. at 2217-19 ("Mapping a cell phone's location over the course of 127 days provides an all-encompassing record of the holder's whereabouts. As with GPS information, the timestamped data provides an intimate window into a person's life, revealing not only his particular movements, but through them his familial, political, professional, religious, and sexual associations.") (internal quotations omitted); $i d$. at 2219-20 ("We therefore decline to extend Smith and Miller to the collection of CSLI. Given the unique nature of cell phone location information, the fact that the Government obtained the information from a third party does not overcome Carpenter's claim to Fourth Amendment protection. The Government's acquisition of the cell-site records was a search within the meaning of the Fourth Amendment.")

175 Id. at 2218. The Court also repeated the "potential dragnet" concern from the Jones concurrence, noting that the extremely low cost of these searches now allows police "secretly monitor and catalogue every single movement of an individual's car for a very long period." Id. at 2217 (quoting Jones, 465 U.S. at 430 (Alito, J., concurring)).

176 Paul J. Larkin, Jr. \& David L. Rosenthal, Flight, Race, and Terry Stops: Commonwealth v. Warren, 16 GEO. J.L. \& PUB. POL'y 163, 163 (2018) ("Police officers find critical the ability to stop, question, and frisk someone who is reasonably suspected of being involved in a crime and of being armed."). 
One possibility is that the courts will adjust the Terry doctrine to change the justification for frisks, thus allowing robots to conduct frisks even though there is no danger to a human officer. Courts could make a number of doctrinal moves to achieve this goal. First, they could argue that a Terry frisk would be justified to protect other individuals in the area. This is a legitimate argument, since a close reading of Terry's language reveals that the Court's justification for the frisk is not always consistent. At two points in the opinion, the Court states that the frisks are justified only so that the officer can protect himself against physical danger. ${ }^{177}$ At four other points in the opinion, the Court states that the power to frisk is justified so that the officer can protect himself or "others." 178 An expansive reading of Terry would allow police officers to conduct a frisk even if the police officer were in no danger, as long as the officer reasonably believed the suspect was a danger to others.

But there are five reasons to reject this expansive interpretation. One is the holding of Terry itself: in applying this new doctrine, the Court only noted the potential danger to Detective McFadden, not to anyone else. Another is Justice Harlan's concurrence in Terry, in which he unequivocally states his own position that the majority decision only permits a frisk for the

177 See Terry v. Ohio, 392 U.S. 1, 23-24, 27 (1968) ("[T]here is the more immediate interest of the police officer in taking steps to assure himself that the person with whom he is dealing is not armed with a weapon that could unexpectedly and fatally be used against him. Certainly it would be unreasonable to require that police officers take unnecessary risks in the performance of their duties. American criminals have a long tradition of armed violence, and every year in this country many law enforcement officers are killed in the line of duty, and thousands more are wounded. Virtually all of these deaths and a substantial portion of the injuries are inflicted with guns and knives .... Our evaluation of the proper balance that has to be struck in this type of case leads us to conclude that there must be a narrowly drawn authority to permit a reasonable search for weapons for the protection of the police officer, where he has reason to believe that he is dealing with an armed and dangerous individual, regardless of whether he has probable cause to arrest the individual for a crime."). Additionally, in a footnote, the Court describes the issue before it as "assess[ing] the need for some form of self-protective search power." Id. at $24 \mathrm{n} .21$ (emphasis added).

178 See id. at 24, 26, 27, 29 ("When an officer is justified in believing that the individual whose suspicious behavior he is investigating at close range is armed and presently dangerous to the officer or to others, it would appear to be clearly unreasonable to deny the officer the power to take necessary measures to determine whether the person is in fact carrying a weapon and to neutralize the threat of physical harm .... Thus [the frisk] must be limited to that which is necessary for the discovery of weapons which might be used to harm the officer or others nearby, and may realistically be characterized as something less than a 'full' search, even though it remains a serious intrusion .... The officer need not be absolutely certain that the individual is armed; the issue is whether a reasonably prudent man in the circumstances would be warranted in the belief that his safety or that of others was in danger .... The sole justification of the search in the present situation is the protection of the police officer and others nearby, and it must therefore be confined in scope to an intrusion reasonably designed to discover guns, knives, clubs, or other hidden instruments for the assault of the police officer.") (emphasis added). 
protection of the police officer, not "from any broader right to disarm." third is the fifty years of jurisprudence following Terry, in which courts have focused exclusively on the danger to the police officer and rarely - if everallowed a Terry frisk in order to protect other individuals. ${ }^{180}$ Fourth is the logic underlying Terry: according to Terry, the police have no right to frisk a suspect until they detain the subject to investigate potential criminal activity. Thus, it is the close interaction with the police officer that creates the potential danger that the Terry frisk is meant to mitigate. Were this not the case, and "danger to others" alone was a legitimate basis for a Terry frisk, police officers could conduct frisks of any individual whom they believe may have a weapon even without conducting a Terry stop - a result that neither Terry nor any subsequent case has allowed. ${ }^{181}$ And a final reason why "danger to others" should not be a legitimate justification for a Terry frisk is that this scenario is already covered by another Fourth Amendment doctrine: the exigent circumstances exception to the warrant requirement. Under the exigent circumstances exception, police are allowed to search an individual if they have probable cause to believe that evidence will be removed or destroyed before a warrant can be obtained and that immediate action is required. ${ }^{182}$ In determining whether the exigent circumstance apply, courts apply a flexible, multi-factor balancing test that is very fact-dependent. ${ }^{183}$ It would be illogical to sweep all of that jurisprudence away and replace it with a "reasonable suspicion" standard just because an individual was the subject of a Terry stop.

Another way in which courts could expand the Terry doctrine would be to allow for a frisk in order to protect damage to police property, i.e., the

179 Id. at 32 (Harlan, J., concurring). Unlike the majority, Justice Harlan never equivocates in his rationale for a Terry frisk; he consistently states that the purpose of the frisk is only to protect officer safety. See, e.g., id. at 34 (Harlan, J., concurring) ("Once [the stop] was justified, however, the officer's right to take suitable measures for his own safety followed automatically.").

180 Supreme Court cases applying Terry have all focused on the danger to the officers, and have not mentioned the danger to others. See, e.g., Ybarra v. Illinois, 444 U.S. 85, 93 (1979) ("Under that doctrine a law enforcement officer, for his own protection and safety, may conduct a patdown to find weapons that he reasonably believes or suspects are then in the possession of the person he has accosted."); Adams v. Williams, 407 U.S. 143, 146 (1972) ("The Court recognized in Terry that the policeman making a reasonable investigatory stop should not be denied the opportunity to protect himself from attack by a hostile suspect.").

181 Terry, 392 U.S. at 23-27.

182 Stephen E. Arthur \& Robert S. Hunter, Federal Trial Handbook $\S 36: 16$ (4th ed. 2018)

183 Courts look to factors such as the gravity and violent nature of the offense; whether there is probable cause to believe the suspect committed the crime; and a likelihood the suspect will escape (or that evidence will be destroyed) if the suspect is not swiftly apprehended. See United States v. MacDonald, 916 F.2d 766, 769-70 (2d Cir. 1990). 
robot itself. In other words, courts could rule that a reasonable suspicion that the suspect posed a risk to police property would balance out the privacy interests of a suspect, so that a frisk for weapons by a robot police officer would be reasonable. This would be a significant shift of Fourth Amendment doctrine, since as of now there are no cases that conclude that reasonable suspicion of risk to property can justify a frisk of a person. ${ }^{184}$

Still, another possibility will be for courts to extend the justification for robot frisks to include the preservation of evidence. Police will argue that when a guilty suspect is stopped by a robot officer, and the field interrogation begins, there will likely be a point at which the suspect knows that he is going to be arrested. At that time the suspect has an incentive to flee and destroy or dispose of the evidence before he is caught. As noted above, the suspect will face an arrest for failing to stop, ${ }^{185}$ but that charge is likely far less severe than the drug or weapons charges he might have faced had he stayed put and submitted to an arrest by the robot. Thus, in order to prevent this occurrence, the robot would need to conduct a frisk of the suspect immediately upon the commencement of the Terry stop, because once the field interrogation results in probable cause, the suspect will flee and it will be too late to detect and seize the contraband. This would involve an extension of the Terry doctrine by the courts, but they would be extending it into relatively familiar ground, since prevention of spoliation of evidence is already a justification for a search incident to lawful arrest. ${ }^{186}$ This adjustment to Terry would merely involve moving the right to search back in time to allow for a preemptive frisk in anticipation of a possible arrest.

184 Of course, a stop could be based on reasonable suspicion that a person was likely to commit a crime involving property damage; a Terry stop could be based on reasonable suspicion of any type of crime. See Adams v. Williams, 407 U.S. 143, 154 (1972) (Brennan, J., dissenting) ("Terry stops are "meant for the serious cases of imminent danger or of harm recently perpetrated to persons or property."') (quoting Williams v. Adams, 436 F.2d 30, 3839 (2d Cir. 1970) (Friendly, J., dissenting)). But a police officer could not conduct a frisk of the suspect during that stop unless she had reason to believe the suspect posed a risk of physical harm to herself.

Also, if police have probable cause to believe that a person committed a property crime, they can obtain a search warrant, or obtain an arrest warrant and conduct a search incident to lawful arrest. But there is no case that has authorized a search based on reasonable belief that the suspect posed a risk to property.

185 See infra note 65 and accompanying text.

186 See Kentucky v. King, 563 U.S. 452, 455 (2011) ("It is well established that 'exigent circumstances,' including the need to prevent the destruction of evidence, permit police officers to conduct an otherwise permissible search without first obtaining a warrant."); Chimel v. California, 395 U.S. 752, 763 (1969) ("[I]t is entirely reasonable for the arresting officer to search for and seize any evidence on the arrestee's person in order to prevent its concealment or destruction.”). 
Equilibrium adjustment could also come from the police themselves. If the courts refuse to expand the Terry doctrine, police could refuse to adopt robot police officers unless the robots had sufficient investigative skills to compensate for the loss of the frisk power. Police departments have already balked at adopting robotic technology unless the robots were able to do everything a live police office is able to do. For example, when a company that designed a prototype of a robot that would interact with drivers during a traffic stop presented its invention to police officers, many of the officers objected that the robot could not look into other parts of the vehicle to conduct a "plain view" search for weapons, drugs, or alcohol. ${ }^{187}$ Also, unlike a human officer, the robot could not detect alcohol on the individual's breath. The company thus plans on upgrading its machine to allow the camera to look around the inside of the car and to include a passive alcohol sensor which could simulate an officer's sense of smell. ${ }^{188}$ In addition to ensuring that robot police could do everything human police can do, the government might only deploy robots that have some of the advanced abilities discussed in the last section, ${ }^{189}$ such as the capacity to scan faces to look for individuals with outstanding warrants, or to scan suspects to learn what they are carrying in their pockets.

If these new powers are not sufficient, and courts fail to adjust the law to allow robot police officers to conduct Terry frisks, some police departments may not see the introduction of robots as an improvement of the status quo. If police departments believe that Terry frisks themselves are effective and necessary to get guns off the street, or to establish dominance over individuals who live in the neighborhoods being policed, ${ }^{190}$ they may prefer to keep human officers on patrol so that they can continue the Terry frisks. Such a choice, of course, would come at a cost to officer safety; the police would choose to continue to put human officers in danger when replacing or supplementing them with robots would allow some of them to do their jobs from a safe distance. ${ }^{191}$ A related issue, which is beyond the

187 See Holley, supra note 57.

188 Id.

189 See supra notes $42-48$ and accompanying text.

190 Not only would robot police officers not be permitted to conduct Terry frisks, which remove a dominance-establishing tool from the police arsenal, but the presence of the robot officers themselves may not succeed in asserting control over the neighborhood in the same way as the presence of human police officers, especially if (as is likely) they are not equipped to use deadly force and they are designed to look benign and non-threatening.

191 Of course, courts might intervene and hold that it is unreasonable to use human police officers if robots offer a less intrusive means of reaching the same goal; however, given the different capabilities of robot officers, and the complex financial decisions a precinct will have to make in deciding whether to replace its human officers with robot officers, it is unlikely that a court will be willing to micromanage police to this degree. 
scope of this paper, is how police unions would react to the introduction of robots. Robots will not replace all police officers, but the future envisioned by this article would realize cost savings and greater efficiency by reducing the number of police officers and having many of their jobs performed by machines. This is likely to give some police officers another, more concrete reason to resist the introduction of robots, regardless of how much safer and more efficient the robots might be.

To get the best of both worlds, police officers may consent to the introduction of robot police, but whenever a robot officer conducts a Terry stop, follow a procedure in which the robot merely orders the suspect to stay in place until a human police officer arrives to conduct the field interrogation. Once a human officer was on the way, the robot would be permitted to conduct a robotic frisk to ensure the safety of the approaching officer. Also, the human officer herself would be permitted to conduct a traditional frisk once she arrived. This procedure would of course put the human police officer in the field at greater risk than if the robot officer conducted the entire field interrogation, but police officers may believe it would be worth the extra evidentiary benefits of a frisk.

Courts, however, might not accept this bifurcated procedure. Under the Terry doctrine, the duration of a Terry stop is limited to a "short period of time"; ${ }^{192}$ thus, the police cannot extend the Terry stop beyond what is reasonable. For example, in United States v. Place, the police conducted a Terry stop of the defendant at the airport, and then ordered him to wait ninety minutes while they transported his bags to a nearby airport, where a drug dog confirmed the presence of cocaine. ${ }^{193}$ The Supreme Court held that under these circumstances, the delay was too long. ${ }^{194}$ More recently, the Court evaluated the length of a traffic stop in Rodriguez v. United States. ${ }^{195}$ In Rodriguez, the police officer completed all the necessary steps of the traffic stop in twenty-one minutes, and then forced the defendant to wait another five minutes for backup to arrive so that the officer could walk his dog around the car to search for narcotics. The Court held that any delay beyond what was necessary to complete the mission of the traffic stop was impermissible. ${ }^{196}$

192 Florida v. Royer, 460 U.S. 491, 500 (1983).

193462 U.S. 696 (1983).

194 Id. at 709 ("[T] interests is an important factor in determining whether the seizure is so minimally intrusive as to be justifiable on reasonable suspicion.").

195575 U.S. 348 (2015).

196 Id. at 354 
Thus, it is an open question as to whether courts would allow police robots to extend a detention until a human police officer arrived. Given the language of Place and Rodriguez, courts are likely to look to whether it was in fact necessary for a human police officer to be on the scene in order to effectively conduct the Terry stop. The reasonableness of a delay for a human officer will be dependent upon the sophistication of the police robot; the more capabilities it has, the less justification there is to wait for a human officer. Another factor would be the response time of the human police officer, since the length of the detention is a factor in its reasonableness. A police department that took full advantage of the efficiencies of robot officers by only deploying a handful of human officers in the field would have a longer human response time to a robotic Terry stop, which would increase the chances the stop would be deemed unreasonable and illegal.

\section{CONCLUSION}

Legitimate concerns for officer safety have been used to justify broad police powers over the past fifty years. The advent of robot police officers has the potential to make policing much safer by allowing police to conduct Terry stops, traffic stops, and even searches and arrests without putting their own lives in danger, which in turn will lead courts to curtail the search powers that are based in officer safety. Robot police will also reduce the need for police to engage in force and deadly force, which means that courts will hold police to higher standards for evaluating when such force is justified. ${ }^{197}$

197 A distinct but related question is how the adoption of robotic technology by civilians will affect the ability of police to conduct surveillance. For example, if self-driving cars become the norm on our streets, the ability for police to conduct traffic stops would disappear. See Rachael Roseman, When Autonomous Vehicles Take over the Road: Rethinking the Expansion of the Fourth Amendment in a Technology-Driven World, 20 RICH. J.L. \& TECH. 1, 3 (2013) (arguing that government will lobby for the right to stop driverless cars even without reasonable suspicion in order to prevent drug trafficking); Jordan Blair Woods, Autonomous Vehicles and Police De-escalation, 114 Nw.L.R. ONLINE 74 (2019) (arguing that traffic stops will become far less common because self-driving cars will be programmed to follow all traffic laws). Currently, police routinely leverage traffic stops into further investigations by using the plain view doctrine to look inside a car to make observations, or using a drug dog during the stop, or asking for consent to search the car. All of these tools will disappear if self-driving cars regularly obey traffic laws. Furthermore, drunk driving checkpoints will no longer be necessary, and the Supreme Court has said that checkpoints to detect criminal activity inside the car are illegal. See generally City of Indianapolis v. Edmond, 531 U.S. 32 (2000) (invalidating a police checkpoint whose primary purpose was to use drug dogs to check for narcotics in the car). Another question is how courts will treat autonomous vehicles with no people inside at all-delivery trucks or autonomous taxis waiting for passengers. Would the owners of these vehicles have the same Fourth Amendment rights as the driver of a car, or would their privacy interests be lower, perhaps allowing for a search of the car on mere reasonable suspicion? 
Robot police will also force changes in numerous other legal doctrines, in ways that may be hard to predict. As semi-autonomous robots become more autonomous, they will begin to make their own decisions in more complicated situations. Eventually a robot officer will approach the abilities of the police robots in science fiction and make its own decision as to when to conduct a Terry stop or a traffic stop. At that point, the algorithms that guide the robot's decision-making process will need to be designed to track the law of reasonable suspicion. The goal would be for these machines to be able to make decisions free of irrational fear or bias; thus, when the robot is deciding to conduct a Terry stop, make an arrest, or employ force, it wouldin theory - make such a decision based only on relevant legal factors. These robots would determine reasonable suspicion based on demonstrably proven correlations and concrete factors, moving beyond the vague intuitions and empirically questionable factors such as "high crime area" or "furtive movements." $" 198$ Of course, modern algorithms that guide police conduct (or judicial conduct) have been subject to significant criticism, in part becauseif not properly designed - they can end up reinforcing existing biases in the system rather than curing them. ${ }^{199}$ These concerns would be even greater if a robot police officer were making its decisions free from human input.

But in the near future, the transition from human patrols to robot patrols will call for a more subtle but still significant change in the legal regulation of police/civilian interaction. Police robots will see and record more than their human counterparts, but they will have far less authority to conduct frisks and use physical force. This will lead to a shift from physical surveillance, with enforcement based on physical compulsion, towards more comprehensive visual surveillance, with enforcement based on legal compulsion. ${ }^{200}$ The result will be a safer, but less anonymous, world.

198 See supra note 95 and accompanying text; see also Floyd v. City of New York, 959 F. Supp. 2d 540, 561 (S.D.N.Y. 2013) (quoting a New York City police officer as describing "furtive movement" as "a very broad concept" which include a person "“changing direction, 'walking in a certain way,' '[a]cting a little suspicious,' 'making a movement that is not regular,' being 'very fidgety,' 'going in and out of his pocket,' 'going in and out of a location,' 'looking back and forth constantly,' 'looking over their shoulder,' 'adjusting their hip or their belt,' 'moving in and out of a car too quickly,' '[t]urning a part of their body away from you,' ' $[\mathrm{g}]$ rabbing at a certain pocket or something at their waist,' 'getting a little nervous, maybe shaking,' and 'stutter[ing]."') (emphasis omitted).

199 See, e.g., Julia Angwin et al., Machine Bias, ProPublica (May 23, 2016), https://www.propublica.org/article/machine-bias-risk-assessments-in-criminal-sentencing; Matt Stroud, The Minority Report: Chicago's New Police Computer Predicts Crimes, But Is It Racist?, VerGE (Feb. 19, 2014, 9:31 AM), http://www.theverge.com/2014/2/19/5419854/ the-minority-report-this-computer-predicts-crime-but-is-it-racist.

200 It will also accelerate the big data phenomenon of collecting and retaining massive amounts of data, which will lead to inevitable questions of data sharing among police departments, and between police departments and other government agencies. 